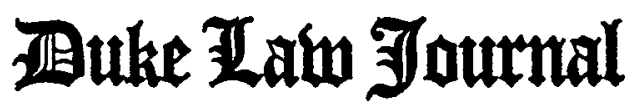

\begin{tabular}{lll}
\hline VOLUME 1976 & SEPTEMBER & NUMBER 4 \\
\hline
\end{tabular}

\section{NARROWING THE DISCRETION OF CRIMINAL JUSTICE OFFICIALS $\dagger$}

\author{
JAMES VORENBERG* \\ TABLE of Contents
}

I. Introduction, Including SOMe Definitions and Recent History _- 652

II. Direct and Indirect Gains From Narrowing Discretion _-_ 661

A. Making the System More Effective or Fair ___________ 662

B. Discretion and the Process of Change _._____________ 666

1. Constraints on Change ___________________ 667

(a) Resources _____________________ 667

(b) Basic values _________________________ 667

(c) Knowledge _-__________________________ 668

2. Excessive Discretion as an Impediment to Change __________ 670

(a) Charging and plea bargaining-the mandatory minimum sen- 670

(b) Pre-trial release ___________________________________ 671

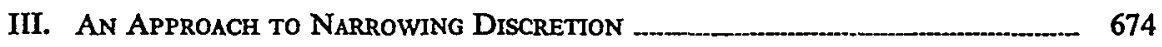

A. Determining Whether and How Discretion Should be Narrowed ___... 674

B. Narrowing Discretion at Key Decision Points ______ 677

1. Charging ____________________________ 678

2. Sentencing_Setting Release Date ______________________ 683

3. Pre-Trial Release _____ 687

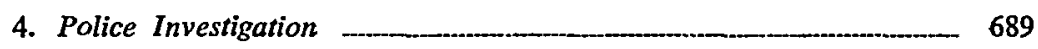

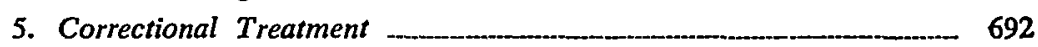

IV. ConCLUSion ___ 694

$\uparrow$ Copyright (C) 1976 by James Vorenberg.

* Professor of Law, Harvard University. This paper, in shortened form, was delivered as the 1976 Brainerd Currie Lecture at Dnke University School of Law. 


\section{IntRoduction, INCLUding Some Definitions AND RECENT HISTORY}

For many years there has been concern about the role of discretion in criminal administration - the extent to which the subjective judgment of an official determines what will be done with a suspect, defendant or convict. The basis for this concern has been the fear that people's lives, liberty and well-being depend on arbitrary, discrimmatory or corrupt decisions.

Quite recently a second line of attack on discretionary decisionnnaking has gained strength. Its premise is that discretion is too often exercised to soften the impact of criminal sanctions, thereby weakening the ability of the criminal justice system to prevent crime. The principal targets of this criticism have been the charging decisions of prosecutors and sentencing decisions of judges in that large inajority of cases where plea bargains determine the final disposition. But similar attacks have been made on magistrates for releasing dangerous criminals too soon, and the police for being soft on drug users and prostitutes.

Both of these assaults describe flaws that are frequent and serious, but they focus on the direct and visible impact of leaving too unuch to individual judgunent. Excessive reliance on discretion has a deeper effect. It hides unalfunctions in the criminal justice system and avoids difficult policy judgments by giving the appearance that they do not have to be unade. It obscures the need for additional resources and makes misapplication of available resources more likely. And it promotes a pretense that we know more than we do, thereby leading to wrong decisions and preempting research and evaluation on which change should be based. Discretionary decision-inaking has helped keep cases moving through the systeen without too many embarrassing 'questions, while promoting the sense that counpassion and wisdom are at work. The result has been soine compassion (often matched or exceeded by unfairness) and very little wisdom.

Narrowing the scope of discretion so that it is no broader than the ability to make intelligent individualized judgments would provide a setting in which major improvements in criminal administration could take place. Administrators, legislatures and the public would better understand questions relating to the balance between individual rights and law enforceinent needs, the allocation of resources, and the extent to which there is sufficient know-how to justify new approaches.

Much of the present literature about discretion in law enforcement deals with consensual crimes, assaultive crimes between friends and 
relatives, or white collar crimes. ${ }^{1}$ These offenses are particularly apt for studying discretion in the initiation of criminal proceedings, because the special nature of the conduct, the circumstances, or the relationship of the parties provide arguments against the full application of criminal sanctions. However, the attention that has been given, for example, to arrests for gambling or minor drug offenses or to guidelines for antitrust violations may have been misleading as to the nature, scope and effects of discretion in the processing of serious predatory crimes. And it is serious crimes, those of greatest current concern, that have raised the strongest doubts about the effectiveness of the criminal system. It does not depreciate the value and importance of studies of arrest practices with respect to vice crimes to note that while the police often fail to arrest for such crimes even when there is clear legal justification for doing so, they exercise very little discretion of that sort in deciding whether to arrest for such crimes as robbery and burglary. Thus, while this inquiry will draw on the prior analyses of discretion, its primary concern is with discretion in processing offenses that have been variously defined as street crimes or common-law crimes. For these purposes it is not necessary to provide a precise list, but the major focus is homicide, rape, robbery, burglary, aggravated assault and grand larceny.

Of course, it is not possible to confine analysis of criminal justice operations strictly to one type of offense. Some vice crimes, such as dealing in heroin, raise the same issues as street crimes, and discretion thus may be exercised with respect to a cluster of related offenses, some of which are victimless crimes and some common-law or street crimes. For example, police may trade leniency on a drug offense to get information about a street crime or vice-versa. Also, the attitudes and practices of public officials cannot be neatly separated by types of crime. Policemen and prosecutors who regard themselves as accountable to no one when they initiate the criminal process for one type of offense will tend to carry over this attitude to all offenses. Conversely, a legislature that decides to limit judges' discretion by providing for mandatory minimuin sentences for a consensual offense, such as dealing in narcotics, is more likely to use inandatory minimums for other crimes it regards as serious.

At the outset, something needs to be said about what is meant by "discretion" and by "narrowing" its scope. For our purposes discretion

1. See, e.g., K. Davis, Discretionary Justice: A Preliminary Inquiry 188-214 (1969); K. Davis, Police Discretion (1975); H. Packer, The Limtrs of the CRIMINAl Sanction (1968); J. Skolnick, Justice Without Trial: LaW ENForcement in a Democratic SOCIETY (1966). 
can best be seen as a residual coneept-the room left for subjeetive judgment by the statutes, administrative rules, judicial decisions, social patterns and institutional pressures which bear on an official's decision. Our system gives no official unlimited discretion and every decision or action involves some exercise of judgment. A precise definition is not crucial since discretion is a relative concept $t^{2}$-more or less free rem for decisions by public officials. As long as this is understood, Judge Breitel's simple definition may suffice: "[P]ower to consider all circumstances and then determine what legal action is to be taken."3

But it is at least worth noting that nore complex issues lurk. Discretion is sometimes used to describe a situation where an official is authorized and rather encouraged by statute to exercise his best judgment with great freedom and little guidance. With very few exceptions this describes the present position of prosecutors in deciding whether and what to charge and of judges im imposing sentence withm statutory limits, if any. Sometimes the official is called upon to apply a standard which purports to direct or guide judgment, sucli as "reasonable suspicion" required for a stop-and-frisk, or "probable cause" for arrest or issuance of a warrant, or "reasonable assurance" that the person will appear for trial, which relates to the condition for pretrial release. The standard may cone with or without guiding judicial interpretations, but in either event the difficulty of reconstructing the facts or obtaining effective review may make the judgment of the official the crucial and fimal determination. And sometimes, as in arrests for traffic offenses or minor assaults between friends or family nuembers, the statute and accepted practice diverge; the law purports to give no scope for individual judgment by the officer, but operates against a long-established usage by which individual police officers decide which instances of clear violation will result in arrest.

The aim of this paper is to consider possible gains from reducing officials' discretionary power, the forms such reduction imight take, and the processes that might lead to such changes. The goal suggested is a system in which decisions are made at the highest level of authority and with the greatest degree of visibility permitted by the nature of the decision and the context in which it is nuade.

2. See R. Dworkin, Is Law a System of Rules?, in Essays IN Legal PhILOsophy 25, 45 (R. Summers ed. 1968):

Discretion, like the hole in a doughnut, does not exist except as an area left open by a surrounding belt of restriction. It is therefore a relative concept. It always makes sense to ask, 'Discretion under which standards?' or 'Discretion as to which authority?'

3. Breitel, Controls in Criminal Law Enforcement, 27 U. CHI. L. Rev. 427 (1960). See also K. DAVIS, DiscretionaRy JUSTICE, supra note 1, at 4-5. 
References to narrowing discretion envision legislative, administrative or judicial action-or a combination of such actions-that inakes it less necessary or possible for an official to rely on his own subjective judgment as to how a matter should be decided. Important issues of policy slould be decided by legislatures not individual officials; where it is reasonable to do so agencies and officials should act in accordance with publicly-proinulgated rules and guidelines; and, except where there is a clear and substantial reason to the contrary, officials should report their decisions and the reasons. If there are situations where there is no reasonable alternative to subjective and invisible exercise of discretion, the authority to make such decisions should reflect a conscious legislative decision rather than a process of arrogation or default. Courts should protect individuals from abuses of discretion but wherever possible do so in a way that avoids undertaking the continuing supervision of how official power is exercised. Instead, they slould encourage legislatures and administrators to issue their own rules and guidelines and to enunciate the bases on which decisions are to be made.

The remainder of Part I is devoted to a brief summary of efforts to reform the nation's criminal justice system since the mid-1960s with particular attention to those developments that bear on discretionary decision-making. This relatively short period is reviewed, notwithstanding that the role of discretion in crimimal administration has been a source of concern for at least half a century ${ }^{4}$ because during these recent years there have been umquely intense and sustained efforts to make criminal administration more effective and fair. And what has been learned, much of it from disappointments, suggests that now may be an opportune time for a major effort to narrow the scope of discretion.

The period since the mid-1960s has been one of great agitation about criminal justice issues-"agitation" rather than "improveinent" because, while some things are better, others are worse and there is no way of making a net appraisal. In any event, the amount said and written about change-and spent seeking cliange-far exceeds what has been accomplished. There have been many sources of the agitation. Most important by far is the fact that serious predatory crime has increased and its impact is felt by most people in the country, particularly those who live in or around cities. In the 1960 s there was debate about whether significant imcreases in actual, rather than reported, crime were taking place, but that issue is now beyond reasonable dispute.

4. See Nattonal Comm'N on Law Observance and ENForcement, Report on LAWLESSNESS IN LAW ENFORCEMENT 6-10, 267-70, 340-47 (1931); NATIONAL COMM'N on Law Observance and Enforcement, Report on Prosecution 18-20 (1931). 
Second, crime and race have become inter-related as major issues. When Senator Barry Goldwater first introduced the phrase "crime in the streets" in the 1964 presidential campaign, he was referring primarily to rioting by blacks. But by the end of the campaign the phrase had come to include individual predatory crime. After the election President Johnson, stung by criticism that he had neglected the issue and believing that crime was one of those problems which government should be able to solve, appointed the Crime Commission and persuaded Congress to enact a federal aid program as part of his "war on crime." One of the findings of the Commission was that blacks, Puerto Ricans and Mexican-Americans commit a disproportionate number of street crimes and are disproportionately victimized. ${ }^{6}$ As issues of criminal justice have become intertwined with such other racially related issues as school integration, white flight to the suburbs, job discrimination and welfare, each has added to the bitterness and intractability of the others.

Third, the United States Supreme Court focused attention on criminal justice issues by major decisions such as those which required counsel at trial, extended the scope of the exclusionary rule, revamped the law relating to searches, confessions and lime-ups, and imposed procedural limitations on correctional decision-makmg. The angry reaction of law enforcement officials and others has made these decisions and other issues of criminal administration subjects of major continuing debate and has fed the politicization of crime as a national issue.

Fourth, the report of the Crime Commission and of other federal commissions combined with publicly and privately financed studies and research projects proposed changes and provided far greater data and understanding about the actual workings of criminal justice agencies than was previously available. ${ }^{7}$

5. Act of Sept. 21, 1965, Pub. L. No. 89-196, 79 Stat. 827 (authorizing funds for the Commission on Law Enforcement and Administration of Justice and the District of Columbia Commission on Crime and Law Enforcement); Law Enforcement Assistance Act of 1965, Pub. L. No. $89-197,79$ Stat. 828 (superseded by 42 U.S.C. $\$ \$ 3701$ et seq. (1970)).

6. See President's Comm'n on Law Enforcement and the Administratton of Justice, The Challenge of Crime in a Free Society 37, 40, 44-45 (1967).

7. See, e.g., ABA Project on Standards for Criminal Justice, Standards Relatting to the Administratton of Criminal Justice (1974); R. Dawson, SentencING: The Decision as to Type, Length, and Conditions of Sentence (1969); JoINT Comm'n on Correctional Manpower and Training, A Time to Act (1969); G. Kassebaum, D. Ward \& D. Wilner, Prison Treatment and Parole Survival: AN EMPIRICAL Assessment (1971); W. LAFAVE, ARREST: The Decision to TAKe a SUSPECT into Custody (1965); F. Miller, Prosecution: The Decision to Charge a Suspect WrTH A CRIME (1969); NAT'L ADVISORY COMM'N ON CIVIL DISORDERS, REPORT (1968); Nat'l Advisory Comm'n on Criminal Justice Standards and Goats, A Nationat, 
Finally, federal aid to encourage and finance changes that began at a modest annual level of six million dollars in 1966 had by the early 1970s reached close to one billion dollars a year. ${ }^{8}$

At the outset, proposals to make the criminal justice system more effective in reducing crime focused on the two ends of the system. It seemed good sense to improve the capacity of the police to catch criminals and, in view of data showing high recidivism rates, to enable correctional authorities to rehabilitate more of thein. There were grounds for optimism about these undertakings. Although some police officials were content to blame the Supreme Court for the imcrease in crime, many departments had chiefs who were more willing than before to try new management techniques, to improve training, and to use communications and computer technology. A large part of the new federal funds was made available to the police for sucli purposes.

Much was written in the sixties about the abuse of police power. ${ }^{9}$ Some of the early proposals and changes were responses to complaints of blacks that police harassed them and treated them more harshly than well-to-do whites. ${ }^{10}$ Police officers were selected and trained with an eye to improving their relations with the public. Under the general rubric of "community relations," police in some cities sought to give at least the appearance of greater accountability to inner-city residents on such matters as stops and arrests for minor crimes, dispersing groups of youths, and responding to calls for help in these neighborhoods. Of course, these moves were partly self-defensive, since several of the large city riots had started with relatively minor exercises of discretionary power by the police, and anger at treatment by the police was an important factor in all the riots.

There is no way of quantifying the continumg effect of such changes. Unquestionably, most large-city police departments now respond with greater sensitivity to mimorities in the exercise of discretion with respect to minor offenses and non-criminal matters. But it is not

Strategy to Reduce Crime (1973); Nat'i Comm'n on the Causes and Prevention of Violence, To Establish Justice, To INSURE Domestic Tranquility (1969); D. Newman, Conviction: The Determination of Guilt or Innocence Without Trual (1966); President's Comm'n on CRIME IN THE District OF Columbia, Report (1966); PRESIDENT'S COMM'N ON LAW ENFORCEMENT AND THE ADMINISTRATION OF JUSTICE, supra note 6.

8. See Act of October 5, 1974, Pub. L. No. 93-433, 88 Stat. 1194, appropriating $\$ 880,000,000$ for purposes authorized by the Omnibus Crime Control and Safe Streets Act of 1968, 42 U.S.C. $\$ \$ 3701$ et seq. (1970).

9. See, e.g., J. SkolNICK, supra note 1, at 80-86 (1967).

10. See Prestdent's Comm'N on Law ENForcement and the Administration of Justice, supra note 6, at 99-103. 
clear that this has much to do with serious predatory crime by or against minorities. ${ }^{11}$

The changes during this period that public debate suggested were most likely to have an effect on street crime were the decisions of the United States Supreme Court referred to above relating to interrogation, lime-ups, arrest, and search and seizure. Although serious crime increased during the time the Warren Court was expanding the rights of suspects in criminal proceedings and seeking to enforce these rights by excluding at trial evidence obtained by illegal means, it has not been established whether or not these changes had any significant effect on the volume of street crime. Conversely, it is unclear whether the Burger Court's narrower definition of rights and less rigorous application of the exclusionary rule has had or will have such effect.

Indeed, the few studies that have been done on the subject leave open the question how much impact application of the exclusionary rule has on police enforcement practices involving serious crime. ${ }^{12}$ This question involves issues outside the scope of this paper, but in view of analysis in later sections it is worth noting here the question whether the Warren Court's expansion of the exclusionary rule as a device to curb abuses of police discretion ${ }^{13}$ may not have preempted legislative and administrative action that might have been more effective in limiting such discretion. For despite the Court's protests that it did not intend to foreclose alternative approaches, ${ }^{14}$ its decisions in the 1960 s probably had that effect.

In sum, there is little evidence that any of the changes or proposals for changes in police practices in exercising discretion have had much effect on the incidence of predatory crime. ${ }^{15}$ And, more broadly, while

11. One of the arguments that is made for good police-community relations is that the police will get better cooperation from people who see or know about serious crime in reporting and testifying. Undoubtedly there are instances where this is true, but the author is not aware of empirical support that shows a significant correlation between community relations efforts and the amount of serious crime, apprehensions or convictions.

12. See, e.g., Model Code of Pre-Arratgnment Procedures (Study Draft No. 1, 1968) 107-49; Oaks, Studying the Exclusionary Rule in Search and Seizure, 37 U. CrI. L. REV. 665, 678-709 (1972).

13. There is a major definitional problem here. Is action by officials which violates standards laid down by the Supreme Court an exercise of discretion? As indicated earlier, no attempt is made here to provide a comprehensive definition. The examples of such actions with which this paper deals are at the borderlines of judicially-enunciated holdings and are included in the discussion of discretion.

14. See United States v. Wade, 388 U.S. 218, 239 (1967); Miranda v. Arizona, 384 U.S. 436, 467 (1966).

15. Perhaps the most significant such effect has been the greater coinplexity in 
the implementation of proposals of the President's Crime Commission and other commissions and study groups-such as improved recruitment, training and supervision of personnel, new communications methods and equipment, and different approaches to organization of departments or to patrol ${ }^{16}$ - has unquestionably inade the police in most places more civilized, there is little basis for believing it has had a significant effect on crime.

Optimism was also high in the late 1960s for progress at the other end of the criminal justice systein. Early research reports on new community-based facilities led the President's Crime Conmission to conclude that treating convicted persons in community settings rather than in prisons would reduce recidivisin rates and, consequently, reduce crime. ${ }^{17}$ And, based more on theory than data, the Commission concluded that if "collaborative" regimens could be established in prisons, the chance of rehabilitating prisoners was greater, since they would learn to take responsibility for their lives and thus prepare to reintegrate into society. ${ }^{18}$ More broadly, there was strong support from administrators and scholars for adequate resources to give group counseling, lower caseloads for probation and parole supervisors and a wide variety of other programs a chance to reduce recidivisin. ${ }^{19}$

Advocates of those changes were not so naive as to promise success. As with proposals to improve the police, recommendations included fine-print warnings that new correctional programs could not really be expected to work miracles. Nonetheless, it was a time of high hopes and, when these hopes took the form of grant applications and "state plans" and "city plans" seeking federal funds, the fine print tended to disappear altogether.

prosecuting criminal cases resulting from a combination of the Supreme Court's decisions on police practices and its decisions assuring counsel for indigents. The result has been to confront prosecutors with the choice, discussed later, of long delays in disposing of cases or accepting a plea to a relatively minor offense.

16. The best piece of research on patrol methods did not show a correlation between visible patrol, generally regarded as one of the most important crime-reducing steps, and the levels of serious crime. G. Kelling, T. Pate, D. Dieckman, \& C. Brown, The Kansas City Preventive Patrol Experiment (1974).

17. President's COMm'N on LAW ENFORCEMENT and the Administration of JUSTICE, supra note 6 , at 170 .

18. Id. at 174.

19. See D. Glaser, The Effectiveness of a Prison and Parole System (1964); Adams, Some Findings from Correctional Caseload Research, 31 Fed. Probation 48 (Dec. 1967); Gronewald, Supervision Practices in the Federal Probation System, 28 Fed. Probation 19 (Sept. 1964); Newman, Concepts of Treatment in Probation and Parole Supervision, 25 FED. Probation 11 (Mar. 1961); Rheiner, The Period of Probation, 26 Fed. Probation 33 (Sept. 1962). 
Giving the police greater latitude for action raised constitutional problems, but there were alınost no such limitations on broadening the discretion to carry out rehabilitation prograins. ${ }^{20}$ And whereas broader police discretion seeined of limited inportance in controlling street crime, it was inplicit in the high hopes for rehabilitation that considerable play be given to professional expertise. For example, it was anticipated that judges, with the advice of probation officers, would use good judginent in deciding who would go to new diversion programs and who needed incarceration and for how long. Similarly, correctional administrators would decide when offenders could inove froin secure to community facilities, or in the other direction, and what kinds of programs would rehabilitate thein most effectively. And parole boards would know when they were ready for release.

Recent discouraging evaluations of programs on which much of this enthusiasm of the sixties was based suggest that giving broad discretion to correctional administrators may be no more lielpful in reducing crime than giving such power to the police. Further research has suggested that the California Community Treatment Project, one of the principal programs on which the Crime Commission based its confidence in commumity treatment, may not have been effective in reducing recidivism. ${ }^{21}$ And perhaps the best single piece of correctional research raises similar doubts about group counseling, on which California and other states rehed heavily as the heart of their rehabilitation programs. $^{22}$ A recent survey of more than 200 rehabilitation prograins reported that most of them had no effect on recidivism. ${ }^{23}$ These findings have been disputed ${ }^{24}$ but even if they are viewed with skepticism it is hard to find programs that can now document successful rehabilitation. It may be that many such programs have not been given a fair chance because of limited time or resources or because they were

20. Most of the judicial decisions limiting the authority of correctional officials discussed in Part III, below, related to the conditions of custody and the exercise of first amendment rights, rather than what may be regarded as the correctional programs.

21. P. Lerman, Community Treatment and Social Control 58-67 (1975).

22. See G. KASSEBAUM, D. WARD \& D. WILNER, supra note 7. It has recently been reported that the California Department of Correction has abandoned rehabilitation in a prison setting as an attainable goal. See Comm'N on Criminal Justice, STATE Bar of California, Report and Recommendations on Sentencing and Prison Reform (1975).

23. Martinson, What Works? Questions and Answers About Prison Reform, THE Public INTEREST 22 (Spring 1974).

24. See, e.g., Palmer, Martinson Revisited, 12. J. Research IN CRIME \& DelinQUEncy 133 (1975). See also Glaser, Achieving Better Questions: A Half Century's Progress in Correctional Research, 40 Fed. Probatron 3 (Jan. 1976). 
changed in midstream, and that it would be a great loss if correctional experimentation and research were to lapse. But optimism about rehabilitation has ebbed, and those who opposed broad discretion on the ground that it may be unfair to convicts have been joined by those who worry that ways in which discretion is exercised nnay result in too lenient treatment..$^{25}$

The experience of the past ten years indicates that despite resources spent on new police methods and experiments with rehabilitation, crime rates contimue to rise. Giving broad discretion to officials at those stages does not seem to make important differences in reducing crime. This, in turn, suggests that we should at least explore shifting the emphasis of efforts to improve criminal justice operations from the two ends of the criminal justice system to the iniddle which may be seen as the "processing" portion of the system. Perhaps by improving decisionmaking about pre-trial release, charging and sentencing, the system can be made more effective in reducing serious crime and more decent in dealing with individuals involved in the criminal process. Thus a major part of the analysis of the possible consequences of reducing our reliance on discretion will focus on the middle portion of the system.

\section{Direct and Indirect Gains From NARROWING DISCRETION}

However interesting it might be to speculate about a system of criminal administration each step of which was defmed with such detail and clarity by the legislature as to be self-executing without a significant role for human judgment, this goes far beyond the goals sought by nnost of those expressing doubts about the present scope of discretionary decision-making. ${ }^{26}$ Even the strongest defenders of discretion would probably concede that narrowing the role of unguided human judginent at some points in criminal administration would be desirable. The issue is more limited-what would be gained by particular changes in the breadth of discretion at particular points in the criminal process? Part II will consider the arguments for narrowing discretion. It will explore, first, the extent to which such narrowing would in itself improve the quality of criminal admimistration involving major predatory crime and, second, whether it would lead to the better understanding of criminal admimistration on which any improvement must be based.

25. See, e.g., J. Wilson, ThinkIng About Crnme 162-82 (1975).

26. But see Goldstein, Police Discretion Not to Invoke the Criminal Process: Low Visibility Decisions in the Administration of Justice, 69 YALE L.J. 543 (1960). 


\section{A. Making the System More Effective or Fair}

In broadest terms, discretion is necessary in criminal administration because of the immense variety of factual situations faced at each stage of the system and the complex interrelationship of the goals sought. In this sense, criminal justice is like other adininistrative processes in which agencies and individuals are carrying out a legislative mandate within constitutional limits and where change and growth may depend on some room for initiative by those administering the laws. The complexity of the goals sought and uncertainty as to whether criminal sanctions can achieve thein, combined with the catastrophic effects on an individual of involvement in the criminal process, offer an especially strong argument for allowing leeway in judgments. But these very features of the criminal process and the lack of generally shared values about the goals of crininal admimistration may also argue for a high degree of certainty about the appropriateness of sanctions and advance notice of their possible imposition, as well as for a consistency of administration that cannot be reconciled with heavy reliance on discretion.

At the outset, one must deal with the argument that without reliance on broad discretionary power, there is no way to take account of all relevant factual variations. Consider sentencing for burglary as an example. By conscientious drafting in greater detail than now appears in any criminal code, a legislature could specify the major scenarios for burglary which it regarded as significantly different from each other in seriousness. These might take account of such factors as whether inhabitants were likely to be present, the type of structure entered, weapons carried, damage done, amount stolen, age, mental condition and motives of the offender. Even assuming that such circumstances as the extent to which such burglaries have become a special problein for the community and the recidivism rate of convicted burglars were treated by the legislature as fixed rather than variable factors, one would end up with a matrix with so many cells as to be inore fit for a coinputer program than part of a criminal code.

But a recognition of the practical difficulties of inaking rules in advance for each of these situations does not lead to the conclusion that judges should be given authority to weigh all the facts and fix the punishment between the least and most serious variations. The alternative is to take account of that number of deviations that can reasonably be provided for in legislation. Thus, for example, a legislature could settle for two permutations of burglary, providing a one-year sentence for simple burglary, and two years for aggravated burglary (weapons, night, building likely to be occupied, etc.). It could then provide a one- 
year increase for each previous serious felony of which a defendant had been convicted and reduction, or graduated reductions, based upon certain personal factors such as age or mental condition, or pressure of circumstances.

Ironically, one of the principal values anticipated in the past from official flexibility in such a situation is precision based on a concern that if there are only a few pigeon-holes, as in the sentencing alternative set forth above, some cases will be forced into the wrong hole. "Wrong" for these purposes means a sentence that, under the circumstances, seems manifestly too lenient or too harsh in relation to prevailing nonns and various purposes sought to be achieved by the sentence. But against this value must be balanced the strong evidence that under our present high-discretion sentencing system there is wide and unjustified disparity in like cases, thus suggesting that since the judges cannot all be "correctly" divining such norms and purposes soine are doing a poor job of it.

This argument against rigidity is often expressed in terms of the need to show compassion; judges need leeway to give light sentences and prosecutors to drop or suspend prosecution where the defendant is not really a bad person or no great harm was done by his conduct. Such leniency lias always been part of the system, and recently it has become institutionalized under the heading "diversion" where the lenient treatment is conditioned on the offender's participation in a "voluntary" treatment program. ${ }^{27}$ Particularly now that such leniency is not a rare event but is practiced wholesale, how is one to decide whether the discretion is being used to show compassion for those who get lenient treatunent, or severity for those who do not? The best example of this problem is plea bargaining. Are the ninety percent who get a reduced punishment because of their cooperation being treated leniently or are the ten percent who go to trial being penalized?

Of course, on many issues specific, pre-set legislative rules are unrealistic. It is hard to conceive of such rules governing the allocation of police investigative resources or employment or treatment assignments of prisoners. In each of those situations issuance of fairly general guidelines miglit in the present state of knowledge represent the only reasonable restriction on administrative action. Indeed, noting the possibility of using a few rigid categories for sentencing is not intended to argue that such an approach is better than permitting some discretion,

27. See Vorenberg \& Vorenberg, Early Diversion from the Criminal Justice System: Practice in Search of a Theory in PRISONERS IN AMERrCA 151 (L. Ohlin ed. 1973). 
but to show that reliance on discretion is not an imperative at all stages of the system.

A second possible reason for relying on discretion instead of rules is to obtain some extra deterrence from the uncertainty. Thus, if the law is clear that every nineteen year-old unarmed day-time burglar will receive probation, some people may rely on this one-bite rule, confident that they face no incarceration until after the first time they are caught. It is an unanswered empirical question whether, if most such offenders receive probation as a matter of judicial discretion, it strengthens or weakens deterrence for all potential burglars or leaves it unaffected. The answer depends on such factors as how well information about penalties actually imposed in particular types of cases is communicated to potential offenders and the extent to which leniency in particular cases gives a general impression of lemiency not borne out by actual practice. ${ }^{28}$ Probably any value an exaggerated impression of the risk of punishment has in buying some extra deterrence is at the lenient end of the punishment scale, i.e., the extent to which it is possible to mislead offenders about the possibility that they will spend at least some time in jail. In fact, one of the strongest arguments made against uncertainty and delay in the criminal process is that they undermine the deterrent effect of sanctions by making the system appear more unrigorous and escapable than it really is.

A third argument for broad discretion is that there are special law enforcement needs, suclı as bargaining for information leading to conviction of an offender seen as more important than the defendant, that would be difficult to define in legislation. Even if one concedes that sucl issues do not lend themselves to detailed, predetermimed and publicized rules, is it so clear that some limiting of subjective judgment by legislation, issuance of guidelines, and after-the-fact disclosure is impossible or undesirable? One can certainly conceive of a generalized policy decision on the kinds of offenses for which such bargaining might be used and the reasons for sacrificing a less important for a more important target.

As already noted, one price paid for granting discretionary power is the risk that the gross sum of the deviation from the assumed legislative norm resulting from individualized judgments will exceed the deviations resulting from the inability to make fine calibrations under a non-discretionary system. Officials by being more lenient or niore

28. See generally F. Zimring \& G. Hawkins, Deterrence: The Legal Threat in CRIMe CONTROL 158-72 (1973); Abrams, Internal Policy: Guiding the Exercise of Prosecutorial Discretion, 19 U.C.L.A.L. REv. 1, 29-31 (1971). 
severe than the legislature would have intended are undermining to that extent the policy embodied in the penal code. Furthermore, the sense of injustice caused by disparate treatment by various individual criminal justice officials is likely to be greater than that caused by the lumping of somewhat dissimilar cases into large legislative categories. This is a source of particular concern in view of the ample evidence that poor people and minorities fare worse in the way discretionary decisions are made about them.

Finally, for the outcome of criminal procedure to turn on subjective judgment rather than announced rules is imconsistent with the right to advance notice of the consequences of one's acts. That some uncertainty is inevitable and has been held permissible should not obscure the dilution of this right that discretionary decision-making entails. At the least, this consideration requires that there be persuasive and substantial reasons for discretionary power and that it not be permitted to be exercised by default.

The case that reduced discretion will make the criminal justice system more effective in reducing crime is less clear. We know very little about how to reduce crime, and therefore it cannot be clearly demonstrated that changing the way decisions are made will reach that result. Perhaps the strongest argument is that common sense suggests that the prospect of greater certainty and speed in punishment, which may be promoted by narrowing discretion, will deter many potential offenders and that at least until the contrary is shown such an approach should be tried and carefully evaluated. Second, because one of the effects of discretion is to obscure what is being done, many predatory offenders whom the legislature and the public would want taken out of circulation for substantial periods may receive too lenient treatment and other offenders may be treated too harshly. Section B analyzes the effects which reduced discretion would have on improving the ability to make such decisions. Perhaps the most that can be said is that narrorwing discretion would provide the potential for greater effectiveness in dealing with crimie and that there is no imdication that broad discretion has helped reduce crime.

Part III of this paper examines the role of discretion at five major poimts in the criminal justice system and considers as to each whether and how discretion should be narrowed. Some of the issues with respect to narrowing discretion are difficult and the proposals speculative. But it is worth noting here that if one accepts the premise that discretionary power should be permitted officials only to the extent that there is a substantial rational basis for it, some issues are not so difficult. 
It seems clear that some of the present grants of discretionary power to criminal justice officials substantially exceed those which would be justified even if the arguments of strong proponents of discretion were accepted, and that without undermining the reasons for some reliance on discretion of officials there can be a major narrowing of its scope. For example, the principal arguments that have been made for letting prison officials impose certain kinds of treatment programs on inmates is the belief or hope that rehabilitation will result. But to permit the continued imposition of such programs after they have been shown not to achieve this end ${ }^{29}$ is to give authority for its own sake. Judicial authority to sentence for a robbery anywhere from probation to a maximum of twenty-five years (or life under the present California indeterminate sentence system $)^{30}$ cannot be supported by any of the arguments for discretion outlined above. Vesting a prosecutor with unlimited, unreviewable, and unguided discretion with no requirement of subsequent explanation of whether and how much to charge is similarly not supportable.

As a first step, it would represent an enormous improvement in criminal administration to eliminate that part of the breadth of discretion that lacks substantial rational basis. The result would be a relatively costless elimmation of much of the unfairness and appearance or fact of undue leniency that now are associated with discretionary decisionmaking.

\section{B. Discretion and the Process of Change}

As outhned in Part I the period beginning early in the 1960s was one of unprecedented concern for inaking the criminal justice system both fairer and more effective in reducing crime. The counbination of increasing crime, law reforn projects and governmental and private studies, and the availabihty of large federal grants designed to make improvement possible and politically attractive offered a rare opportunity for a major overhaul.

There are many reasons why so hittle progress has been made. This section explores the proposition that the criminal justice system's heavy reliance on discretion was and is an important part of the explanation and that one result of carving down that reliance would be to encourage

29. See, e.g., G. Kassebaum, D. WARD \& D. WiLnER, supra note 7, at 313-17, 32224.

30. See Cal. Pen. Code $§ 1168$ (West 1970). 
policy judgments that now go unmade and thereby provide impetus for change that is now held in check.

1. Constraints on Change. Efforts to improve the criminal justice system must take account of the general effects of inertia on social change, including the natural resistance of those working in criminal administration who see their jobs or their accustonned modes of operation threatened. In addition, the availability of resources, basic value judgments such as those reflected in judicial decisions on constitutional issues, and the level of knowledge (or know-how) are major constraints on change. One of the effects of extensive reliance on discretion is to impede the judgments about those constraints that are necessary as a basis for rational change. A brief analysis of the role and interrelationship of those constraints will show how reliance on discretion introduced a "fudge factor" into the process of change.

(a) Resources. In some respects the role of resources in reducing crime or making criminal admimistration more decent is obvious. We could pretty much eliminate burglary if each home and busmess had an elaborate alarm systein and if there were enough private guards or police to respond promptly to alarms. We could eliminate street robberies, rapes and assaults by providing armed escort service. Some of the crimes suppressed in these ways might appear in other places or forms, but that would depend on how broad the program of "target-hardening" was. Similarly, spending money to build more comfortable jails for persons held awaiting trial and to hire enough judges and well-trained lawyers for ail defendants would clearly make the system more decent and fair. Many believe that making judges work harder and spending enough on the court system to cut backlogs would reduce crime by making the deterrent threat of punishment more effective, but that has not yet been established empirically.

Of course, the effects of applying additional resources are not always clear. Some changes that could be effected with additional resources imight carry costs that were not monetary. Thus, in view of high recidivism rates, crime would almost certainly be reduced if every convicted offender were locked up for the rest of his life. That could be done, however, only at enormous costs in terms of both resources and such basic values as compassion and forgiveness.

(b) Basic values. Some kimds of changes that clearly are inconsistent with our basic values would almost certainly reduce crime. Thus if, as in China, Russia, and, to a lesser extent, many Continental countries those accused of major crimes had no opportunity for pre-trial release, or if parolees were electronically momitored to track their where- 
abouts and activities, ${ }^{31}$ some reduction in serious crime would almost certainly result. And it might be possible to convict more dangerous crimmals if the police could arrest without probable cause and use torture to elicit confessions, although that is less clear. As noted above, life sentences for all felons would probably also reduce crime, but they would undermine the value placed on coinpassion and forgiveness. Similarly, increasing the numbers of police and guards to prevent burglaries would affect privacy.

Some of the changes that have actually taken place in the last few years have raised questions of basic values although in a less drastic or clear-cut forin. Many of those changes relate to procedural rights of suspects and defendants and are a result of decisions of the Supreme Court expanding such rights. The New York legislation requiring life sentences for drug violators and the closing of the Massachusetts juvenile institutions are polar examples of such changes.

(c) Knowledge. Lack of knowledge, or know-how, is the most absolute of the constraints. If knowledge of how to achieve a goal such as rehabilitation of an offender simply does not exist, there is no option, comparable to the spending of vast resources or the sacrificing of fundamental values, that will enable us to achieve it. The closest we can come is to mvest heavily in research in the hope that we will learn sometime in the future.

The best example of how lack of knowledge affects the process of change is the choice annong basic strategies aimed at reducing crime. Such strategies include:

(1) Making it harder to commit the crime ("target-hardening") by using locks, hights, dogs, watchmen, garages under buildings, for example;

(2) Incapacitating offenders from committing additional crime-for some kinds of white-collar crime such as tax fraud, merely identifying a person as a violator may result in sufficient future surveillance as to reduce the risk, but for street crime it generally means incarceration; (3) Deterring commission of crime by the threat of punishment, which presumably depends on the likelihood of being caught and convicted and the unpleasantness of the resulting punishment;

(4) Rehabilitation-making a person less dangerous in the future by offering or imposing some kind of treatment.

31. See Schwitzgebel, Issues in the Use of an Electronic Rehabilitation System with Clrronic Recidivists, 3 L. \& Soc'Y Rev. 597 (1969); Note, Anthropotelemetry: Dr. Schwitzgebel's Machine, 80 HaRv. L. Rev. 403, 418 (1966). 
Dealing with the underlying social and economic causes of crime is not included in the foregoing list of crime-reduction strategies because this paper focuses on clranges in the criminal justice system. One unay believe, as the author does, that in the long run the nnost important steps that can be taken to reduce crime lie outside the criminal justice systein and require confronting issues of income redistribution and racial justice, yet still be concerned with analyzing what changes in criminal justice operations may make a difference.

Of the four crime-reduction strategies, we know a good deal about the first two and very little about the second two. With enough resources people can protect theinselves against most of the so-called street crimes. Fences, alarms, locks, doormen and watchmen, taking taxis or private cars instead of walking, all are demonstrably helpful, and this partly explains why poor people are disproportionately victimized. We also know how to keep people out of circulation by locking thein up. But, in addition to the constraints that cost and humanity impose on this form of incapacitation as a major crime-prevention strategy, we do not know whether some of the crime-reduction benefit of incarceration is offset by the criminalizing effects of prolonged imprisonment, assuming release at some time. This enpirical question is complex. Even if incarceration makes people more dangerous if they are released when they are relatively young, there is some evidence of "burning-out" in iniddle age, ${ }^{32}$ so the age of release may be a critical factor; and the conditions of incarceration may make a difference. ${ }^{33}$

On the other hand, despite the heavy reliance on the threat of punishnient-general deterrence-by legislators in setting punishment levels and judges in inposing sentences, very little that is solid and persuasive is yet known about deterrence. ${ }^{34}$

As indicated earlier, a bitter debate is underway on how much is known about rehabilitation, but the lieat of it far exceeds the range of disagreennent. Some would argue that, despite the optimism of the 1960s and a good deal invested in research, virtually nothing is known about how to make criminals less dangerous. Others would say that a

32. See D. GLASER, supra note 19 , at 302 .

33. Unfortunately what we know about target-hardening and incapacitation relates primarily to the extremes. We know very little about the results of modest efforts to make commission of crimes more difficult or, as indicated in the text, the effect on crime of relatively brief incarceration.

34. For a general discussion of the subject, including proposals to develop knowledge, see F. ZIMring \& G. HaWkins, supra note 28. And for discussion of some recent studies on the significance of severity and certainty of punishment, see J. WILson, supra note 25 , at $173-76$. 
few correctional programs have succeeded and we have learned a hittle. But it would be hard for even the most optimistic to argue on the basis of present know-how that rehabilitation can be regarded as a major or even a significant crime-reduction strategy.

2. Excessive Discretion as an Impediment to Change. Any rational proposal for significant improvement in criminal administration requires an understanding of the interrelationships of the three major constraints referred to atove. If knowledge exists as to how to achieve a goal, it should be put to use. If it does not, it is crucial that action not be taken on the mistaken assumption that it does. The costs represented by spending money or changing rules or practices that embody basic values may be unnecessarily incurred if other ways are known or could be discovered to accoinplish the goal. They may be futilely incurred if belief that the goal can be achieved is based on inadequate or faulty inforination. Furthermore, it is important to understand the relationship between resources and values. Often, without conscious decision, values such as liberty, compassion and decency are being sacrificed because of inadequate resources.

The nature, reasons, and effects of present practices must be understood as a basis for considering possible change. Two examples are set forth below to show how discretionary decision-making may obscure the information required for inaking responsible change, and weaken the incentive to seek it.

(a) Charging and plea bargaining-the mandatory minimum sentence issue. Prosecutors have broad power over the charging decision and its use in the plea bargaining process. For many years plea bargaming has been under attack as being unfair to defendants who must choose between forfeiting their right to a trial and running the risk of a higher sentence if convicted after trial. Recently, increased concern about crime has led to attacks on sentencing judges and on prosecutors for agreeing to bargains that include light sentences for serious offenses. One manifestation of this concern has been the call for mandatory minimum sentences. ${ }^{35}$

In fact, the attack on judges and prosecutors as being soft on crime is mostly unfair. There is jittle reason to believe that prosecutors or judges favor light sentences for street crime any more than do their critics. What has happened is that prosecutors, the officials who have

35. See, e.g., "Governor [Rockefeller] Asks Life Term for Hard-Drugs Pushers and for Violent Addicts," N.Y. Times, Jan. 4, 1973, at 1, col. 6; Kennedy, "Punishing the Offenders," id., Dec. 6, 1975, at 29, col. 1; "President [Ford] Urges Stiff New Laws on

Violent Crime," id., June 20, 1975, at 1, col. 8. 
most at stake in maintaining the flow of cases through the courts, have been buying the elimination of cases from the pipeline by offering light sentences.

Policy decisions of enormous potential importance are avoided through this exercise of discretion by the prosecutor. The problem here is not lack of knowledge. If we want people charged and tried for the crimes they actually commit rather than for some lesser offense we know how to do it. Enough judges, courtrooms, prosecutors, defense lawyers, clerks, probation officers and prisons must be added so that there is no pressure on officials to bargain for lenient treatment. Permitting the prosecutor to handle the matter through his charging discretion obscures the fact that the systein has reacted to the pressure of increasing numbers by sacrificing a basic value-punishment appropriate to the crime-in order to avoid investing additional resources. The reason for this decision-by-default is that it is the only one the prosecutor can control, since it is the legislature that would have to decide to spend more. If the prosecutor did not have the power to trade down charges for pleas or chose not to use it, an even larger backlog of criminal cases and greater over-crowding of jails housing unbailed defendants would put more pressure on the legislature to make a conscious judgment about the resource-value questions which now is not being made by anyone.

Of course, a legislature might be tempted both to save money and to get high sentences by setting the sentences to be imposed following plea bargains at what it thought was deserved in view of the seriousness of the crime and raising the maximun level for those who go to trial high enough to pressure nrost defendants to plead. The maximun level would probably have to be very high since what now induces a large percentage of guilty pleas is the opportunity to get probation or a suspended sentence. If some period of incarceration were likely after a guilty plea, inany defendants would take their chances on a trial unless they faced a much longer sentence for conviction at trial than upon a plea. With this clearcut an attack on the right to a trial, courts might well find such plea bargaining a violation of due process.

(b) Pre-trial release. In most jurisdictions there are no stated standards that magistrates are required to follow in deciding about pretrial release. They almost never write opinions or say in court why they are setting bail or other release conditions, and they are rarely subject to effective review. As a result, bail-setting can be and is used as a way of holding people thought to be dangerous, even though the likelihood of appearance at trial is supposed to be the issue. This exercise of discre- 
tion results in avoidance of policy issues of enormous significance both to individual liberty and to crime reduction.

Probably the inost important issue is whether it would be better to abolish money bail and hold only those found to present a serious risk of flight or of committing additional crimes while awaiting trial. The immediate reaction of many to such a system is that it violates the presumption of innocence and that sacrificing that value is too great a price. This response appears conclusive until one recognizes that many poor people are now being held who would be released if they were rich enough to buy a bail bond. A further argument against such a system is that we do not know enough to predict dangerousness. But what if it could be shown (as is probably true) that at least as much overprediction of dangerousness is taking place under the guise of setting bail at a figure that will ensure reappearance as could be anticipated under a so-called preventive detention system?

In addition to these questions which relate to value judgments and knowledge, there are inportant resource issues. A system that limited pre-trial detention to thirty days, with incarceration in a motel-like facility of the sort used for sequestered juries, with opportunities for families and friends to visit freely and for the accused, accompanied by a guard, to go out to help his lawyer prepare for trial perhaps might evoke a different reaction to the notion of preventive detention than did the preventive detention legislation for the District of Columbia that has become almost a dead letter. ${ }^{36}$ Preposterous? Coddling? Surely the expenditures cannot be opposed on grounds of primciple, since it is only fair to acknowledge that the accused in pre-trial detention is like the sequestered juror being held solely for the convenience and security of society.

One cannot help worrymg that a relatively civilized scheme such as that outlined above might deteriorate for lack of funds, that the motel would become a jail, the thirty days would change to sixty or 180 or be subject to exceptions that would deprive it of effect, and the definition of "dangerous" would expand. Despite this risk, it still seems desirable that the central issues of policy, and the facts on which policy can be based, not be obscured. The existence of virtually invisible and unreviewable judicial discretion guarantees that the issue will remain buried in a morass of unexplored assumptions about the inability to predict dangerousness, costs in terms of liberty, or dollars, and the effect of

36. See Hermann, Preventive Detention, A Scientific View of Man, and State Power, 1973 U. OF ILL. L.F. 673, 680. 
changes on predatory crimes. Only if we fear what policy makers would do if they understood the consequences should we prefer a system where discretion impedes the ability to confront issues that might lead to change.

Section A of Part II argued that narrowing discretion would, in itself, constitute an important improvennent in the quality of criminal justice. There is therefore a partially circular quality to the argument that one of the reasons for narrowmg discretion is to enable policy makers to understand better the operations and effects of criminal administration so they can make miprovements. But, as the preceding examples indicate, the changes that would be promoted by eliminating some of the fog with which broad discretion surrounds parts of the system go far beyond the direct benefits of limiting discretionary power discussed in Section A.

It would be naive to assume that if the public and legislators were simply presented witl clearer and harsler pictures of what is really liappening, they would make changes. Louis Jaffe has argued, in response to Kemieth Davis' proposal for a formal regulation of police use of informers, ${ }^{37}$ that "[1]ittle would be gamed by the regulation other than making public what the society prefers not to inake public."38

There is no way of measuring what the legislature and the public "know" and have affirmatively decided to keep buried because that is more coinfortable, and what is simply going by default. Of course, a society can decide not to confront an issue. But there are so many

37. See K. DAvis, Discretronary JUSTICE supra note 1 , at 96.

38. Jaffe, Book Review, 14 VIIL. L. REV. 773, 777 (1969). Jaffe continues:

This under-the-counter approach may offend the Puritan, it may offend the legal theorist, but I am sure that those who are offended are in a rather small minority, and if a society-a democracy if you will-chooses to operate that way, the appeal to general principles of equal protection and formal legality does not seem to me to be sufficient. Id.

See also M. KADISH \& S. KADISH, Discretion to Disobey 77-78 (1973), discussing police discretion:

A criminal code has symbolic offices to fill. The unequivocality of the criminal prohibition and the threat of punishment for transgressors contribute something-how much is problematical - to the deterrent and moralizing force of the criminal law. Relying on police interposition avoids proclaiming outwardly that the law is not meant to be taken literally. Furthermore, it avoids acknowledginent of the extent to which important matters, even those directly affecting the citizen's liberty, are left to the official's discretion-an acknowledgment that would undoubtedly be an affront to the rule-of-law tradition. We are not arguiug that it is better to permit the police to operate outside the rules than to recognize their discretionary authority and seek to control it within a rational structure, thereby ensuring equal treatment of citizens before the law. Our point is rather that the device of not formally delegating discretionary authority and relying on the police to make-hopefully-sensible and sensitive judgments outside the stated rules of their competence is an alternative strategy that serves identifiable social purposes. 
indications of the low level of understanding of criminal justice issues by the public, legislators and other policy inakers and so inucl demonstrable harm done by the way broad discretion is exercised that one should be quite clear about the decision "not to make public" before letting that consideration discourage efforts to narrow discretion.

\section{AN APProach to NARROWING Discretton}

The process of narrowing discretion involves relationships between courts, legislatures and criminal justice officials that take different forms at different poimts along the system and in different jurisdictions. This paper does not offer detailed and comprehensive prescriptions for changing the criminal justice system's reliance on discretion. What is attempted here is to offer suggestions and examples about a process of change that over time would eliminate much of the unjustifiable discretion from criminal adıninistration.

\section{A. Determining Whether and How Discretion Should Be Narrowed}

The clearest case for limiting discretion is where its exercise violates individual rights. ${ }^{30}$ Thus courts have intervened where they found that police practices in conducting searches, interrogations and line-ups and correctional treatınent of prisoners violated specific constitutional protections. There have been similar but less frequent examples of courts invalidating on constitutional grounds the way bail-setting, sentencing and charging authority have been used..$^{40}$

In criminal justice, perhaps even more than in other areas where control of administrative agencies is involved, there has been almost sole reliance on judicial intervention to remedy and prevent violations of personal rights. While courts have no choice but to take action when presented with clear violations, there are serious limitations in seeking to remedy officials' abuse of power on a case-by-case basis. ${ }^{41}$ Application

39. See note 13 supra.

40. Many will sense a major analytic gap at this point. In a system of criminal justice where everything from the definition of crime to eligibility for parole seems biased against the socially and emotionally disadvantaged, it may seem arbitrary to select some and omit other discretionary decisions as violating fundamental rights. Nonetheless, it seems worthwhile to treat in a separate and more limited category those decisions where the way discretion is exercised violates recognized basic rights and leave for other consideration the extent to which the broader system within which decisions are made results in inherent unfairness.

41. Cf. Shapiro, The Choice of Rule-making or Adjudication in the Development of Administrative Policy, 78 HARv. L. Rev. 921, 936-40 (1965); Stewart, The Reformation of American Administrative Law, 88 HARV. L. REv. 1667, 1784 (1975). 
of the exclusionary rule to police misconduct in individual cases seems to have had limited impact, and maintenance of continuing supervision of prisons has put courts in the position of exercising authority without the resources or personnel to effect necessary changes. Abuses could be better prevented if officials "internalized" decent practices and restraints, and if legislatures which have the leverage of continuing control, particularly over funding, could undertake closer responsibility to prevent such abuses. It is not clear how courts can best use their responsibility to enforce individual rights so as to encourage these processes. The U.S. Supreme Court's recent decision in Rizzo v. Goode $e^{42}$ mdicates the Court's reluctance to let the federal courts intrude on the discretion of police departments, and its language is broad enough to raise doubts about soine of the cases in which lower federal courts have supervised the overhaul of prisons and jails. ${ }^{43}$ Perhaps courts can promote the process of internalization by making it clear that in considering the relief to be given in particular cases they will give considerable weight to legislative and agency efforts to create a system where abuses are less likely. ${ }^{44}$

Even where the exercise of discretion is not shown to violate individual rights, there are points in the criminal justice system where discretionary power is clearly broader than any rational arguinent made for such power, and this should be a signal that narrowing is appropriate. Included are situations where reliance on officials' judgment can only be justified by knowledge or expertise which they do not have or where the breadth of choice permitted to an official exceeds the maximum range which the legislature would desire if it considered the question. Also included are exercises of discretion designed to save resources but which have now become too costly in terms of other values or goals. The best example of this is the power over the terms of plea bargains which seeins to have been left to prosecutors at a time when the effects of plea bargaining were less important or less well understood

42. 423 U.S. 362 (1976).

43. The Court reversed the district court's order, pursuant to 42 U.S.C. $\S 1983$ (1970), that the Philadelphia Police Department revise its internal disciplinary and civil complaint procedures. The Court's emphasis on lack of definitive involvement of the high-ranking officials who were the defendants may help distinguish police agencies from prisons which are operated with much closer supervision and involvement by top administrators. It is striking that neither the majority nor the dissent discussed the relationship between the civil rights action in Rizzo and the exclusionary rule cases. See also Conlisk v. Calvin, 96 S. Ct. 1093 (1976), vacating and remanding 520 F.2d 1 (7th Cir. 1975).

44. See note 96 infra. 
and which by a process of default rather than affirmative policy is now seen as their prerogative.

The reasons for narrowing discretion discussed in Part II suggest a series of inquiries to guide the process.

First, does the decision involve a major policy issue fit for legislative action that is now left by default to the judgment of individual officials? Identifying an issue as "fit" would involve such questions as whether there is an adequate empirical basis for a decision and whether there is sufficient acceptance of the advantages of a clear-cut preannounced rule to justify the kind of long-term arbitrary line-drawing and lumping of somewhat diverse cases that is involved in legislative action. ${ }^{45}$ If an issue is not yet ripe for such clear-cut legislative determinations, one possible alternative is the use of legislative guidelines which identify the factors to be taken into account or which indicate a preferred order among possible actions to be taken. ${ }^{46}$

Second, are policies and practices of the official or agency relating to the issue for decision clear enough so that it makes sense that they be promulgated subject to future change? There will be different degrees of confidence in the detailed elaboration of such policies and practices and in their ripeness for disclosure as guides to agency action, and the determination of whether formal rule-making, publication of operating manuals or directives, or informal guidelines should be used might depend on these differences. ${ }^{47}$ These factors might also determine the extent to which such statements should be subject to judicial review, although the impact of review on the time and resources required for processing cases would also be relevant.

Finally, are there decision points where discretion is too broad but where there is not enough systematic data available about the factors on

45. See Bator \& Vorenberg, Arrest, Detention, Interrogation and the Right to Counsel: Basic Problems and Possible Legislative Solutions, 66 CoLUM. L. REv. 62, 63 (1966).

46. See, e.g., Bail Reform Act of 1966, 18 U.S.C. $\$ \S 3146-52$ (1970); MoDel Prenal Code $\$ 305.9$ (Official Draft, 1962).

47. This paper does not attempt an analysis of where rulemaking, in the sense used in the federal Administrative Procedure Act, 5 U.S.C. $\$ 553$ (1970), should be used and where more informal processes by which agencies make public their standards and procedures are appropriate. See K. Davis, DisCRETIONARY Justice, supra note 1, at 102103. In general, Professor Davis' enthusiasm for rulemaking by criminal justice agencies scenis sound, but in some parts of the system which have operated invisibly it would represent an important first step if more tentative statements were made available. See Davis, An Approach to Legal Control of the Police, 52 Texas L. REv. 703 (1974). See also Parole Commission and Reorganization Act $\$ 2,18$ U.S.C. $\$ 4218$ (Pub. L. No. 94233, 90 Stat. 219 (Mar. 15, 1976)). 
which decisions are made or where the policies and practices are simply too incoherent to provide a basis for any advance statement of how decisions will be made? Here it may be necessary at the outset to settle for after-the-fact public reports of particular decisions or groups of decisions, with some indications of the reasons for them in the hope that as a body of reported experience accumulates agency guidelines would be the next step. ${ }^{48}$ There seem to be only three types of justification for not reporting reasons: the burden that reporting would impose, unfairness to individuals in revealing the results of investigations before charges are brought, and harm to law enforcement processes in disclosing certain kinds of information. Each of these presents a variety of further factual questions and value judgments. It is fairly clear that disclosure of the results of some actions, such as grand jury investigations, would violate due process rights. And, while the scope of such an exception is difficult and controversial, some kinds of information, such as the identification of still active underground informants, should clearly be exempt from immediate disclosure. For present purposes it is sufficient to note that these are fit subjects for analysis and should not be allowed to go by default.

\section{B. Narrowing Discretion at Key Decision Points}

The general terms in which the foregoing approach to narrowing discretion is expressed make it obvious that its application to major decision points of the criminal justice systen will encounter difficulty, compounded by uncertainties as to how decisions are presently made. Nevertheless, some directions for change are rather clearly suggested, and where such clarity is not possible, important empirical issues are disclosed that suggest lines of further inquiry. The ensuing sections will undertake such an analysis, looking first and at greater length at charging and sentencing, the "middle" portions of the system where the case for narrowing discretion seems clearest, and turning then to pre-trial release, pohice investigation, and corrections. ${ }^{49}$

48. See Jaffe, Administrative Findings or the Ameer in America, 34 CORNELl L.Q. 473, 491-93 (1949).

49. Jury discretion is omitted not because it is unimportant, but because it is not viewed as a distorting element in the system, and because it comes into play in very few cases. Of course, if drastic enough changes were made in jury trials it would have an important effect on the "processing" portion of the system generally since it would affect the proportion of defendants who plead guilty. But despite the importance of shifts to non-unanimous jury verdicts in some states, changes in the role of jury discretion are not being, and hopefully will not be, seriously pursued as a way of making the system more effective in dealing with crime. Also excluded are other decision-makers, such as 
1. Charging. The prosecutor's decision whether and what to charge is the broadest discretionary power in criminal administration. ${ }^{50}$ In jurisdictions where felony cases begin by indictments, the charging decision is in theory that of the grand jury. But with rare exceptions, if the prosecutor really wants an indictment, the grand jury will give it to him. ${ }^{51}$ Instances of grand jury decisions not to prosecute are likely to reflect indifference by the prosecutor or use of the grand jury to insulate him agamst public criticism for dropping a case he believes should not be pursued. ${ }^{52}$ While supporters of the grand jury system talk of runaway

magistrates sitting at first appearance or preliminary hearings and grand juries, each of whom typically exercise less discretion than they are given.

50. See generally F. MILLER, supra note 7, at 151-350. The decision to investigate, usually first made by the police, is at least as free of external control. But where a suspect as to whom there is probable cause is identified in a serious street crime, it is usually clear that some investigation must follow. The decision as to the effort to be devoted to such investigation is discussed in Section 4 infra.

The origins of the great power of prosecutors are not clear. See P. Howard, Criminal Justice in England 386-87 (1931); Langbein, Controlling Prosecutorial Discretion in Germany, 41 U. CHr. L. Rev. 439, 443-46 (1974); Comment, The District Attorney-A Historical Puzzle, 1952 Wis. L. Rev. 125. See also K. Davis, DiscreTIONARY JUSTICE, supra note 1 , at 189 :

Why these various assumptions are made is not easy to discover; the best short answer seems to be that no one has done any systematic thinking to produce the assumptions, but that the customs about prosecuting, like most other customs, are the product of unplanned evolution.

Comparative studies suggest that prosecutors in Continental countries exercise far less discretion. See id. at 191-95; Damaska, Structures of Authority and Comparative Criminal Procedure, 84 YALE L.J. 480, 517-19 (1975); Langbein, supra at 443, 446 et seq. But until there has been closer comparison of the workings of American and foreign criminal justice operations on a systematic basis, one should probably be cautious in assuming that the latter are non-discretionary. See Goldstein, Reflection on Two Models: Inquisitorial Themes in American Criminal Procedure, 26 STAN. L. REV. 1009, 1020 (1974):

Despite the central tendencies, the usual contrast between European and American procedure is too superficial. It compares inquisitorial theory which encompasses the entire process from investigation to conviction with accusatorial and adversary theory which have generally addressed only the contested trial and have until recently ignored the guilty plea and pretrial investigation. When we compare events from initial investigation to adjudication and sentencing, the two systems tend to converge.

See also Rosett, Trial and Discretion in Dutch Criminal Justice, 19 U.C.L.A.L. Rev. 353, 365 (1972).

51. See Johnson, The Grand Jury-Prosecutorial Abuse of the Indictment Process, 65 J. Crim. L. \& Criminology, 157, 160-61 (1974); Morse, A Survey of the Grand Jury System, Part II, 10 Ore. L. Rev. 295, 363 (1931); Shannon, The Grand Jury: True Tribunal of the People or Administrative Agency of the Prosecutor?, 2 N.M.L. REv. 141, 146, 166-67 (1972).

52. See Moley, The Initiation of Criminal Prosecutions by Indictment or Information, 29 MiCH. L. REv, 403, 413-14 (1931); Note, Evaluating the Grand Jury's Role in a Dual System of Prosecution: An lowa Case Study, 57 Iowa L. Rev. 1354, 1372-73 (1972); Project, Perspectives on the Administration of Justice, 57 Iowa L. REv. 598, 630 (1972). 
grand juries which keep the prosecutor honest, it is rare for a grand jury to insist on an indictment the prosecutor does not want. ${ }^{.3}$ In the federal system, the prosecutor can refuse to sign the charging papers even if the grand jury decides to indict. ${ }^{54}$

Traditionally, American courts have circumscribed prosecutorial discretion only on the basis of discrimination "deliberately based upon an unjustifiable standard such as race, religion, or other arbitrary classification." 55 Recently a number of courts have set aside convictions or enjomed prosecutions where the defendants were arbitrarily selected from a large group of potential defendants, even without a showing of discrimination on the basis of a forbidden classification. ${ }^{56}$ And in a few cases courts have set aside prosecutions found to have been brought for the purpose of intimidation or harassinent. ${ }^{57}$

Cases in which courts have limited prosecutorial discretion have generally involved vice crimes, regulatory offenses or other situations where a large number of known violators are not being prosecuted. Typically with street crimes the issue of discretion involves the reduction of charge in return for a guilty plea or other cooperation. As to such exercises of discretion, Chief Justice (then Circuit Judge) Burger's often-quoted statement in Newman $v$. United States reflects the prevailing view of the courts:

Few subjects are less adapted to judicial review than the exercise by the Executive of his discretion in deciding when and whether to institute criminal proceedings, or what precise charge shall be made, or whether to dismiss a proceeding once brought. ${ }^{58}$

53. See Note, The Grand Jury: Powers, Procedures, and Problems, 9 ConuM. J.L. \& Soc. PROB. 681, 686, 702 (1973).

54. See United States v. Cox, 342 F.2d 167, 171 (5th Cir. 1965).

55. Oyler v. Boles, 368 U.S. 448, 456 (1962); see Yick Wo v. Hopkins, 118 U.S. 356 (1886).

56. See, e.g., Simonetti v. City of Birmingham, 55 Ala. App. 163, 314 So. $2 d 83$ (Crim. App.), appeal denied, 314 So. 2d 99 (Ala. 1975); State v. Vadnais, 295 Minn. 17, 202 N.W.2d 657 (1972); People v. Acme Markets, Inc., 37 N.Y.2d 326, 334 N.E.2d 555, 372 N.Y.S.2d 590 (1975).

57. E.g., United States v. Falk, 479 F.2d 616 (7th Cir. 1973); United States v. Steele, 461 F.2d 1148, 1152 (9th Cir. 1972) ("An enforcement procedure that focuses upon the vocal offender is inherently suspect, since it is vulnerable to the charge that those chosen for prosecution are being punished for their expression of ideas, a constitutionally protected right.").

58. Newman v. United States, 382 F.2d 479, 480 (D.C. Cir. 1967). A few recent cases suggest lines of reasoning which, if extended, might provide a basis for attacking the exercise of discretion in street crime cases. See, e.g., State v. Zornes, 78 Wash. 2d 9, 25, 475 P.2d 109, 117 (1970); State v. Blanchey, 75 Wash. 2d 926, 939-40, 454 P.2d 841, 850 (1969). And in People v. Birmingham, 13 Mich. App. 402, 164 N.W.2d 561 (1968), the court refused to upset the prosecutor's use of the multiple offender statute, 
A very few prosecutors with large staffs have issued guidelines on charging policy and practices, including plea bargaining. ${ }^{50}$ The primary motivation has been dissemination of information within the offices, and the guidelines are drafted with enough leeway to avoid giving up flexibility, undoubtedly reflecting in part a reluctance to further complicate the criminal process by giving defendants an additional basis for motions and review.

Charging discretion is sometimes exercised to reflect the prosecutor's belief that the circumstances call for leniency, but its most important use is in plea bargaining. In most jurisdictions, the incentive offered a defendant to plead guilty in a case involving a common law felony is a reduction of charges to a less serious felony or a misdemeanor-robbery to larceny or assault, burglary to larceny or trespass, rape to attempt or assault. In the last ten years plea bargaining has been brought out of the closet; typically the judge will be aware of the deal and it may be explicitly set forth on the record. In soine jurisdictions, where judges rely heavily on the prosecutor's recommendation, the negotiations may be about the sentence recommendation rather than the charge.

It seems clear that no valid purpose is served by the enormous breadth of prosecutorial discretion and that it represents power resulting from default rather than a conscious legislative judgment. The most drastic limitation on prosecutorial discretion would be a legislative mandate that the prosecutor charge the most serious offense for which he concludes there is probable cause. Such legislation, which would eliminate bargaining for charge concessions, would have to deal with how many related offenses, including lesser included offenses, should be charged. It would alinost certainly include an exception for charge concessions used to get information about more important defendants.

The process of developing such legislation would force the legislature to consider carefully the substantive criminal code. The ultimate impact of such a change would depend on the form of sentencing statutes. If the present broad range of sentencing were maintained, the

but made it clear that it would have done so if it had found "caprice" or "invidious discrimination" in the exercise of discretion. Id. at 407, 164 N.W.2d at 563. But cf. Imbler v. Pachtman, 424 U.S. 409 (1976), in which the Supreme Court upheld the doctrine of prosecutorial immunity in the context of civil suits under section 1983, 42 U.S.C. $\$ 1983$ (1970); see Note, Quasi-Judicial Immunity: Its Scope and Limitations in Section 1983 Actions, 1976 DUKE L.J. 95.

59. See, e.g., District Atrorney of Harris County, Texas, The Prosecutor's Discretton: A Statement of Policy (1974); District Atrorney of King County, WASHINGTON, GUIDELINES (1976). 
result would be not to eliminate discretion but to transfer to judges that broad power now exercised by prosecutors. Unless judges themselves took an active role in negotiations, prosecutors' ability to bargain would depend on whether judges accepted prosecutorial sentencing recommendations or were authorized to accept pleas to lesser offenses.

It is clearly unrealistic, except perhaps in the very long run, to assume that such legislative specification would take place. Certainly the slow progress of state legislatures and Congress in enacting coherent criminal codes suggests that pursumg such an approach for the purpose of encouraging greater specification in the criminal codes would be quixotic. $^{60}$

Even with such specification, the variety of behavior which meets the definition of a crime and the relevance of personal characteristics of the offender and of the surrounding circumstances may make it desirable that there be some leeway in setting the level of charges. This might suggest that the legislature should undertake to specify the circumstances under which a reduced charge should be brought. While many of the factors that justify such reduction are clear, the charging policies of prosecutors have been so obscure that substitution of legislative specification is probably premature. There is not yet a body of reported experience that legislatures can appraise and use as guides in their own specification, although they unight obtain some of this information by holding hearings and drawing on the little empirical research that has been done. ${ }^{61}$

Acceptance of this view does not, however, support continuation of the enormous power prosecutors now exercise over the charging decision, with virtually no accountability. Even if it is premature for legislatures to limit this power by substituting their own standards, there is no reason why they should not require prosecutors' offices to issue and keep current public guidelines that describe the circumstances under which they will charge less than the maximum ${ }^{62}$ and that deal with the inultiple charge issue. And as part of the framework for such

60. Even recently enacted criminal codes assume modulation where the prosecutor thinks leniency is appropriate, so elimination of such discretion would require further statutory revision. If there were no prosecutorial discretion, some of this modulation would presumably take the form of juries or judges convicting of lesser included offenses.

61. See generally F. MILLER, supra note 7.

62. A prosecutor would understaudably be reluctant to publicize a "one-bite" rule on such offenses as shoplifting. This raises both the free deterrence and fair notice issues discussed earlier. In any event, this problem probably does not have much bearing on the street crime issue, where even the reduced charge is likely to present a risk of incarceration. 
guidelines, legislatures should take responsibility for determining if plea bargaining for reduced charges is to be continued and, if they determine that it should not be, for tying that determination to provision of enough resources to permit the trial of the larger number of cases that will result. If the argument is accepted that major issues of policy should not be decided by default, there is no reason for a decision of that sort to be left to the discretion of the prosecutor and the trial judges, as is the present pattern.

For example, a legislature might determine that plea bargaining is permissible only when the prosecutor determines that he needs information and testimony froin one defendant against others whose conviction is more important. Or a legislature might authorize the prosecutor to agree with a defendant whose first offense involves no violence and who makes some form of restitution that he will plead to an offense carrying limited or no incarceration. The legislative authorization could be quite general and could be coupled with a mandate that prosecutors issue guidelines speeifying the circumstances in whicli such bargaining would be used and the terms of restitution that would be acceptable. ${ }^{63}$ Public reports on each use of this authority to bargain, disclosing how the prosecutor had exercised his discretion, would enable the legislature to determine whether further action on its part was required. This exainple is not offered as a proposal but rather to give some concreteness to the view that legislatures have an intermediate choice between default and preemption on this issue.

Finally, it should be noted that sucli an approach would have to include consideration of whether the individual defendants could cliallenge the prosecutors' rules and their fair application in particular cases. The extent to which an administrator's violations of his own guidelines provides a basis for judicial relief may affect not only the punctiliousness of his compliance, but also his willingness to issue the guidelines, since permitting such challenges would open up a new major level of litigation, with more resulting delay and a need for greater resources. ${ }^{.4}$ While this paper does not seek to resolve this important and complex issue, ${ }^{65}$ it is worth noting that it would not be unreasonable for a legislature to see

63. For an example of a proposed general statute calling for guidelines, see MoDeL Code of Pre-Arraignment Procedure $\$ 350.3$ (2) (Official Draft, 1975).

64. For reference to this issue as it relates to police arrest policy see W. LAFAvE, supra note 7 , at 158.

65. See Note, Violations by Agencies of Their Own Regulations, 87 HARv. L. Rev. 629 (1974). See also Billiteri v. United States Bd. of Parole, 400 F. Supp. 402 (W.D.N.Y. 1975) (the court found the Board had failed to comply with its own guidelines and ordered the petitioner released). 
the process of limiting discretion as one proceeding in stages over a long period and to conclude that it would not allocate resources to such challenges unless a system of public reporting revealed that the regulations themselves or the degree of agency compliance with then were unsatisfactory. ${ }^{68}$

2. Sentencing-Setting Release Date. ${ }^{67}$ There is no way to describe succinctly the nation's fifty-one sentencing schemes. For present purposes it is enough to note that there is a high degree of indeterminacy in the sentences that can be imposed by judges for most serious offenses in most jurisdictions. ${ }^{68}$

Sentencing discretion within statutory limits is not quite as broad as prosecutorial discretion. A few states give judges relatively narrow ranges between the minimum and maximum sentences they may impose for some offenses, and some have enacted high mandatory minimums for certain offenses or for repeated offenses in an attempt to eliminate "down-side" judicial discretion altogether. A number of jurisdictions provide for appeal of sentences and, even in the absence of such statutes, a few appellate courts have set aside sentences as unreasonable or have required that reasons be given for some kinds of sentences. ${ }^{69}$ And in some jurisdictions judges have developed a number of voluntary devices such as sentencing councils and institutes to minimize disparity. ${ }^{70}$

Setting the release date, normally the function of the parole board, is integrally related to the sentencing decision. The most common pattern of sentencing statutes is to give the judge authority to determine the minimum time to be served and the parole board authority to determine the maximuin, usually within an outside figure set by the judge or sentencing statute. But there are many variations in how authority is shared between the judicial and executive branches. Within the range of their statutory authority parole boards have traditionally

66. See Abrams, supra note 28; cf. MODEL CODE of Pre-ARraignMent Procedure $\S 350.9$ (Official Draft, 1975).

67. The Supreme Court's treatment of discretion in the recent capital punishment cases, while generally relevant to the discussion here, is in such a special context that it sheds only limited light on the role of discretion in sentencing and determining release date. See Gregg v. Georgia, 96 S. Ct. 2909 (1976), and companion cases.

68. See abA Comm. on Correctional Facilities and Services, Resource Centter on Correctional law and Legal Services, Sentencing Computation laws and Practice, A Preliminary SuRvey (Jan. 1974).

69. See, e.g., Butler v. District of Columbia, 346 F.2d 798 (D.C. Cir. 1965); United States v. Wiley, 278 F.2d 500 (7th Cir. 1960).

70. See Task Force on adminstration of Justice, President's Comm'n on Law ENFORCEMENT AND AdMINISTRATION OF JUSTICE, TASK ForCe REPORT: THE COURTS 2326 (1967). 
been recognized as having broad discretion in setting the release date. ${ }^{71}$ However, some states have recently adopted statutes requiring that parole boards give reasons for the demal of parole ${ }^{72}$ and several courts have required such reasons either as part of due process ${ }^{73}$ or, for federal prisoners, pursuant to the Administrative Procedure Act. ${ }^{74}$ And, in addition to requiring reasons for denial of parole, some courts are less prepared to assume that boards have properly exercised their discretion in denyimg parole. ${ }^{75}$

For many years the principal attack on discretion im sentencing and parole was based on disparity of punishment among offenders. In large numbers of cases it is siniply not possible to find a rational basis to explain the relationship of one sentence to another. ${ }^{76}$ Recently a second

71. See Parsons-Lewis, Due Process in Parole Release Decisions, 60 CAL. L. Rev. 1518,1532 (1972) ("The courts have rejected every attempt to import a single incident of due process into the parole-release procedure").

72. See, e.g., ILL. REv. Stat. ch. 38, \& 1003-3-5(f) (Supp. 1974); N.Y. CorRec. LuW $\$$ 214(6) (McKinney Supp. 1975). See also Parole Commission and Reorganization Act \$ 2, 18 U.S.C. § 4206 (Pub. L. No. 94-233, 90 Stat. 219 (Mar. 15, 1976)).

73. See, e.g., Childs v. United States Bd. of Parole, 511 F.2d 1270 (D.C. Cir. 1974); United States ex rel. Johnson v. Chairman, N.Y. State Bd. of Parole, 500 F.2d 925 (2d Cir.), vacated as moot, 419 U.S. 1015 (1974); In re Sturm, 11 Cal. 3d 258, 521 P.2d 97, 113 Cal. Rptr. 361 (1974). See also United States ex rel. Richerson v. Wolff, 525 F.2d 797 (7th Cir. 1975); Haymes v. Regan, 525 F.2d 540 (2d Cir. 1975) (state parole board need not disclose general criteria on which release decision is based when specific reasons are given). Note that Scott v. Kentucky Parole Bd., cert. granted, 423 U.S. 1031 (1975), dealing with the application of due process to parole release proceedings, is pending before the United States Supreme Court.

74. See, e.g., Mower v. Britton, 504 F.2d 396 (10th Cir. 1974); King v. United States, 492 F.2d 1337 (7th Cir. 1974). See also Project, Parole Release Decisionmaking and the Sentencing Process, 84 YALE L.J. 810, 858-61 (1975). The Administrative Procedure Act has also been held to require notice to permit coinment on U.S. Parole Board guidelines. Pickus v. United States Bd. of Parole, 507 F.2d 1107 (D.C. Cir. 1974). Congress dealt with the application of the APA to parole proceedings in the recently enacted Parole Commission and Reorganization Act $\S 2,18$ U.S.C. $\S 4218$ (Pub. L. No. 94-233, 90 Stat. 219 (Mar. 15, 1976)). Decisions involving the grant, denial, unodification or revocation of parole are no longer judicially reviewable under the Act, although the result of King and Mower is accomplished by a legislative requirement that reasons be given for a denial of parole. Id. $\S 4206(b)$. The general rulemaking process is to be covered by the Act and will be subject to judicial review-recognizing the principles of Pickus. See CONFERENCE Report on PAROLE COMMISSION AND Reorganization ACt, H.R. Rep. No. 94-838/S. Rep. No. 94-648, 94th Cong., 2d Sess. 36 (1976).

75. See, e.g., Nelson v. Railsback, 12 CRMM. L. RPTR. 2076 (7th Cir. 1972); In re Minnis, 7 Cal. 3d 639, 498 P.2d 997, 102 Cal. Rptr. 749 (1972). But see Scarpa v. United States Bd. of Parole, 477 F.2d 278 (5th Cir.), vacated and remanded, 414 U.S. 809 (1973), vacated as moot, 501 F.2d 992 (5th Cir. 1973). See also Childs v. United States Bd. of Parole, 511 F.2d 1270, 1281 (D.C. Cir. 1974).

76. See generally M. Frankel, Crmminal Sentences 12-25 (1972). 
line of attack has been based on growing empirical support for the proposition that no one knows how to achieve rehabilitation or to predict who will refrain from crime after release. ${ }^{77}$ These concerns have combined with frustration about increasing crime and what appear to be lenient sentences in some places and anxiety that prisoners feel in not knowing when they will be released to make sentencing reform the most fashionable current issue in the field.

The issues relating to sentencing and setting of the release date are in many ways similar to prosecutorial discretion in that no good purpose or need justifies the present breadth of discretion. One important difference, however, is that over-charging by the prosecutor is subject to correction by acquittal or by conviction only of a lesser included offense at trial, while sentencing excesses are subject only to such control as the legislature provides or to executive clemency. On the other hand, under-charging is no more correctable at trial than too lenient sentencing. Furthermore, there is not quite as strong a tradition of virtually unlimited discretion for sentencing as for charging.

In terms of the approach suggested here there is a more important distinction. Immediate legislative action on sentencing seems more appropriate than such action on charging because there is in existence a large body of information to guide legislative judgments about the sentencing process, much of it generated by those judges who have sought information and guidance in exercising their broad power. ${ }^{78}$ In addition, it is possible to determine the reasons for sentences imposed from the experience in states that permit appellate review.

Some legislatures have sought to respond to the part of the problem that concerns them most-lenient sentences-by enacting statutes setting mandatory minimums. For reasons discussed earlier such statutes are likely to be ineffective in achieving the goal if prosecutors are left with discretion as to what to charge and are imder pressure to plea bargain.

A sounder approach would be for a legislature to evaluate present data and opinion about rehabilitation, deterrence, incapacitation and desert as bases for punishment and to consider what outer limits of severity and leniency it wants for various offenses under various circumstances. Recent data and analysis suggesting that judges and parole boards are probably in no better position than is the legislature to set

77. See A. von Hirsch, Doing Justice: The Choice of Punismants 19-26 (1976).

78. See, e.g., A. Partridge \& W. Eldridge, The Second Circutr Sentencing Study (1974). 
the term should encourage a narrowing of the range between the least and greatest punishment an offender will receive. ${ }^{78}$ A number of variations on this general theme are possible. The most extreme in terms of eliuninating discretion would be "on-the-nose" sentencing with no parole. A more moderate approach of providing very narrow ranges between maximun and minimum sentences and specifying when probation or suspended sentences may be used (presumably defined by the nature of the offenses and prior tecord) makes sense in order to gain sonie experience with sharply reduced discretion. While the narrower range would make giving reasons less important as a control on discretion, requiring a statement of reasons would help the legislature judge how permitted leeway is being used, even if considerations of resources and promptness lead to a decision against allowing individual appeals.

A third variation recently proposed would have legislatures set a single "presumptive" sentence but allow the sentencing judge some himited leeway for aggravating or mitigating variations if he explains the reasons. ${ }^{80}$ A fourth would have legislatures establish an administrative body or panel of judges to set the specific sentences or ranges of sentences within a broader range dictated by the legislature. ${ }^{81}$

Each of these variations would eliminate the parole board's enormous present power to set the release date. ${ }^{82}$ And, except for the "on-

79. See N. Morris, The Future OF IMPRISONMENT 31-34 (1974); A. voN HIRSCH, supra note 77, at 102-04.

80. See A. von Hirsch, supra note 77, at 99-101; Dershowitz, "Let the Punishment Fit the Crime," N.Y. Times, Dec. 28, 1975, § 6 (Magazine), at 7.

81. See S. 2699, 94th Cong., 1st Sess. (1975) (introduced by Sen. Edward M. Kennedy and others), 121 CoNG. REc. 20,514-16 (daily ed. Nov. 20, 1975).

82. Maine has recently enacted legislation that abolishes the role of the parole board in deciding on release date:

Another change proposed in the sentencing system is the requirement that persons sentenced to imprisonment be confined for a definite period, rather than for the indeterminate term now characteristic of the law. Release will no longer depend on parole board decisions but on the willimgness of the prisouer to earn the "good time" deductions authorized by law. Educational, vocational and other programs may still be offered prisoners, but the realization that there is no known program that can act as a "cure" for criminality makes it irrational to rely on program participation as some sign of rehabilitation. Lund (Chairman, Maine Criminal Law' Revision Commission), "Introduction to the Proposed Code," im ME. Rev. STAT. ANN. tit. 17-A at xix (1975).

The former parole provisions were repealed [Me. LAws $1975 \mathrm{ch} .499]$ and were replaced by a system of specific sentences subject to good time deductions. ME. REv. STaT. ANN., tit. 17-A, $\S \S 1253,1254$ (1975). However, section 1154 authorizes the Department of Mental Health and Corrections to petition the judge to resentence the offender if "the department is satisfied that the sentence of the court may have been based upon a misapprehension as to the history, character or physical or mental condition of the offender, or as to the amount of time that would be necessary to provide for protection of the public from such offender...." One commentator has called this section "a 
the-nose" proposal, each represents a combination of greater legislative responsibility for sentencing decisions with an imposition on the sentencing judge or an administrative body of an obhigation to disclose the bases for decision either in advance or after the fact or both.

3. Pre-Trial Release. The decision on pre-trial release is of enormous importance to the defendant, simce, in the event of a decision not to allow release, his punishment is in effect beginning before trial. ${ }^{83}$ Almost everywhere he is held in the same jails that house convicted offenders. In jurisdictions where the docket is crowded he may actually serve as long or longer in jail awaiting trial as he would serve if sentenced, and being in jail weakens his position in plea bargaining. ${ }^{84}$ Pretrial release decisions undoubtedly have soine effect on the amount of serious crime but it is not clear how great that effect is.

Assessing the role of discretion in pre-trial release is complicated because three fictions make it difficult to determine on what basis decisions are now being made. First, the issue nominally considered is whether the defendant will show up for trial, since this is the only issue the Supreme Court has identified as legitimate. ${ }^{85}$ In fact, what is usually on the minds of magistrates and prosecutors (on whose recommendation inagistrates often rely) is whether the defendant will commit

masterpiece of breathtaking ambiguity" and has said that "the indetermmate sentence, having been banished by the front door, has returned through the rear." Zarr, Sentencing, Commentaries on the Maine Criminal Code, 28 ME. L. REv. 117, 144 (1976).

83. The issue of pre-trial release was alluded to earlier as an example of the way in which discretion makes it difficult to confront major policy issues. See II $B(2)(b)$, supra. The issues discussed there were abolition of money bail as a condition of release and detention on the basis of dangerousness. It is worth noting that inost of the issues relating to the scope of discretion discussed in this section would have to be faced under a system such as that hypothesized earlier. It would still be important to provide guidance to magistrates for the determination of dangerousness and in the choice of alternative conditions, although it would probably be easier to deal with discretion since the issues as to which it was exercised would be more easily identified.

84. The following excerpt from a record in a New York City trial court is an example:

Plea bargaining session in a New York City Court, Summer 1973-Class A misdemeanor assault with weapon:

DA (to police officer): "Is $\mathbf{3 0}$ days all right?"

Police Officer: "Okay."

(The DA and Legal Aid lawyers then got together and the Legal Aid lawyer agreed to 30 days. But then ... .)

Judge: "T've got to have another 15 days. This guy is going to kill soinebody."

DA (to Legal Aid): "Tell him he'll sit in jail through the whole summer wait-

ing for a jury part if he doesn't want to accept a plea."

Legal Aid: "Plea accepted."

Judge: "Sentenced to 45 days."

J. Vorenderg, Criminal Law and Procedure 827 (1975).

85. Stack v. Boyle, 342 U.S. 1, $4-6$ (1952). 
another crime while awaiting trial. ${ }^{88}$ The second fiction is that the amount of nnoney bail a defendant posts to obtain his release determines the likelihood of his appearing at trial. Occasionally the defendant or a family neinber will post collateral that will provide an incentive for appearance, but once the premium for a bail bond has been paid the defendant is unlikely to be concerned about a forfeiture and the bondsinan rarely produces a defendant who would otherwise abscond. Almost always the issue for the magistrate is not how nuch bail will make the released defendant reappear, but how high it must be set in order to prevent release.

The third fiction has to do with the way discretion is exercised. As with most discretionary decisions, the implicit assumption is that by applying informed and experienced judginent to the facts the magistrate will reach a wise decision that fairly balances the defendant's interest in freedoin and the state's interest in having him show up at trial. This standard is not often achieved. Often all that is known about the defendant is the arresting officer's version of the crime and the defendant's prior criminal record.

Determination of whether a given exercise of discretion in setting terms of release violates fundamental constitutional rights is complicated by uncertainty as to what is being decided. Setting higher bail than the defendant can pay does not violate present judicial interpetations of the constitutional prohibition against "excessive" bail. ${ }^{87}$ The existence of a pre-trial release system based on money arguably denies equal protection, but this view has not prevailed in the courts. ${ }^{88}$ While there are unquestionably many instances in which courts set bail at levels or in circumstances that violate constitutional provisions on bail or equal protection, the availability of judicial relief through a motion to reduce or habeas corpus weakens somewhat the argument for narrowing the magistrates' discretion in order to protect fundamental rights.

Constitutional questions aside, there are nonetheless strong reasons for legislatures to take more responsibility for the way decisions are made. The issues of how much risk of nonappearance should be taken and what alternatives to money bail should be used in various circumstances are major policy judgments involving a balance of law enforce-

86. Other considerations may include the availability of cell space in the jail, intimidation of witnesses, and whether the police or prosecutor are likely to find it convenient to have access to the defendant before trial.

87. See, e.g., United States v. Radford, 361 F.2d 777, 780 (4th Cir.), cert. denied, 385 U.S. 877 (1966); White v. United States, 330 F.2d 811, 814 (8th Cir.), cert. denied, 379 U.S. 855 (1964).

88. See, e.g., Schilb v. Keubel, 404 U.S. 357 (1971). 
ment interests and fairness to individuals. They should not be left to the judgunent of individual magistrates without some legislative guidance. The federal Bail Reform Act has provided some direction on the issue of alternatives to bail by setting forth in ascending order of restrictiveness an array of conditions short of imcarceration with direction to the inagistrate to use the least restrictive condition that will assure appearance at trial. ${ }^{89}$

Some courts have developed guidelines as to who will be released on recognizance or other condition and who will be held in custody. The New York City Criminal Court, which was the pioneer in this process, put into effect a program developed by the Vera Institute of Justice under which arrested persons were given numerical scores in accordance with a system that awarded poimts for such factors as length of local residence, family ties, lack of serious criminal record, and einployment. Vera staff members made telephone checks to determine the point score and a defendant who achieved a prescribed score would be released on his recognizance. The good rate of appearance at trial has led several other jurisdictions to adopt a similar approach. ${ }^{90}$ Many jurisdictions use an even simpler system for early disposition of cases at the stationhouse, involving predetermined schedules, on the basis of which the police set the conditions of release. Experience with such guidelines inay provide the basis for future legislative specification of who is to be regarded as an acceptable risk. ${ }^{91}$

Some of the recent pre-trial release statutes require a inagistrate who has set a condition for release that the defendant cannot ineet to state the reasons for doing so. ${ }^{92}$ The imunediate purpose is to provide a basis for judicial review, but the reasons will provide a source of data which will enable legislative bodies to consider whether they are satisfied with the way discretion given by the statute is being exercised.

4. Police Investigation. The police investigative practices that have been subjected to judicial scrutiny through application of the exclusionary rule-search and seizure, interrogation and line-ups-have already been referred to as examples of the difficulty in case-by-case judicial review as a means of preventing abuse of discretion. If the $\mathrm{Su}-$ preme Court had taken a less expansive and detailed approach to these

89. 18 U.S.C. $\S \S 3146-52(1970)$.

90. Note, Administration of Pretrial Release and Detention: A Proposal for Unification, 83 YaLE L.J. 153, 156 n.6 (1973).

91. National Conference on Bail and Crmmanal Justice, Bail and Summons: 1965 xiv-xv (1966); Feeney, Citation in Lieu of Arrest: The New California Law, 25 VAND. L. REv. 367 (1972); Note, supra note 90, at 156-57.

92. See, e.g., D.C. CODE ANN. §§ 23-1321(d)-(e) (1973). 
issues, legislatures might have taken more responsibility for developing a framework of rules and more police departments might have proinulgated and enforced specific guidelines for officers. Coinmon sense suggests that the Court's decisions must have been soinewhat preemptive, but in some agencies they may have persuaded officials that they should issue guidelines to prevent violations. After the Court's detailed inandate to the police in Miranda $v$. Arizona ${ }^{33}$ there was certaiuly a drop in interest among bar, law reform and law enforcement groups in the detailed provisions on interrogation and the conditions for police custody of the American Law Institute's Model Code of Pre-Arraigninent Procedure. The author knows of some police officials who prior to Miranda were actively exploring internal guidelines, including sound recording of interrogations, aimed at avoiding litigation over the voluntariness of confessions, but who felt that the new burdens imposed by Miranda were all that they should take on.

One issue on which the Warren Court left a good deal of room for legislative and agency action was police authority to stop-and-frisk, and perhaps this offers an example of what might be accoinplished by the approach to narrowing discretion suggested here. In Terry $v$. Ohio ${ }^{94}$ the Court somewhat grudgingly approved a stop on less than probable cause. It required that there be a reasonable basis for suspicion but left open such issues as what kinds of crime will justify a stop, when a frisk is permitted, and how intense it may be. And it did not deal with the practice in soine cities of so-called "field interrogation" by which large numbers of people, even on the basis of slight suspicion, may be "asked" by the police to identify themselves and explain their presence. These practices are seen by police who use thein as important in dealing.with serious street crime and by many who are subjected to them as abusive and discriminatory. Enough is known about the use and abuse of such practices to enable legislatures to deal with certain najor questions, for example, the suspected offenses for which a person can be stopped, the length of detention, and the circuinstances when a frisk is justified. The Model Pre-Arraignment Code includes such provisions relating to stopand-frisks, and a few states have enacted provisions based on the Code. ${ }^{95}$ In addition, several departments have adopted more detailed guidelimes relating to stop-and-frisks. ${ }^{96}$ On the other hand, the broad

93. 384 U.S. 436 (1966).

94. 392 U.S. 1 (1968).

95. Model Code of Pre-Arraignment Procedure § 110.2 (1975); id. App. IX-C.

96. See Arizona State Univ. College of Law and Police foundation, Model RULES FOR LAW ENFORCEMENT—STOP AND FRISK (1974).

Judge Carl McGowan of the Court of Appeals for the District of Columbia Circuit 
use of field interrogation has only recently been openly acknowledged by some departments, and it probably inakes sense to start by requiring that departments using it make public whatever guidelines they issue for officers and report fully on the circumstances and consequences as a basis for possible legislative action. ${ }^{97}$

Where police discretion may have the greatest impact on serious street crime is in those sections of departments known variously as the detective bureau or investigation division. Since officers working on investigations characteristically operate invisibly and without supervision the best one can do is draw inferences from a few snatches of data and many subjective impressions. What is available suggests that the choices by detectives of which cases to investigate and how much energy and resources to invest are probably the police decisions that are inost significant for street crime. Unfortunately, there is also some reason to believe that in inany departments the detective function may be performed inefficiently and ineffectively. Glimpses of the handling of investigations reinforce the worry that opportunities to solve crimes and nuake arrests are being lost. This is not surprising in view of the inethods and criteria for selecting detectives from the force and the limited supervision of their work. Probably what are involved here are not simply decisions to be lenient, but a melange of ad hoc judgments (including niany by default) about how to use resources, combined with primitive techniques for obtaining and processing information.

Most aspects of the detective function seen clearly not ripe for legislative specification or formal administrative rule-nnaking. Because of the secretiveness of decisions about which crimes or types of crimes should be investigated and what investigative techniques such as undercover agents, paid informers, or wiretapping should be used, there simply is not now enough information on which it would be possible for the legislature to act except in the most general terms. This secretiveness which has characterized both local police and the FBI niakes it impossible to judge whether the agency itself has clearly enough formulated policies and practices to enable it to issue guidehines. ${ }^{98}$ All large

has suggested that, in considering whether to suppress evidence as illegally seized, the courts might give weight to the efforts of a department to prevent violations by developing and enforcing its own rules. See McGowan, Rule-Making and the Police, 70 Mich. L. Rev. 659, 689-90 (1972). See also United States v. Perry, 449 F.2d 1026, 1037 (D.C. Cir. 1971).

97. See J. Boydstun, SAN Diego Field Interrogation Report (Police Foundation 1975).

98. A few departments have recently permitted studies of their investigative functions. See P. Greenwood \& J. Petersilia, The Crmminal Investigative Process (1975); P. Bloch \& C. Ulberg, Auditino Clearance Rates (1974). 
agencies must have some written memoranda for intra-agency communication, and a first step would be for such materials to be disclosed subject to the needs for confidentiality of some items noted earlier. A second step would be after-the-fact reporting, with as much specification of particular cases as possible, on how investigative resources were allocated, what methods were used, and what results were achieved.

5. Correctional Treatment. Much of the decision-making by those in charge of convicted persons takes a form different from that described in the preceding sections. The issue is not whether or how long a person will be subjected to the criminal process ${ }^{99}$ but rather his living conditions and activities and the restrictions on his freedom. If he is on probation or parole, the extent of control over daily routine is obviously much less, and the nature and effects of a decision to impose or reimpose incarceration has many similarities to the charging and sentencing decisions.

The most dramatic curbing of discretion in an area traditionally left to the control of administrators has been the assault by the courts on the so-called "hands-off" doctrine. Unlike suspects in the hands of the police, for whom the recognition of the enforcement mechanismexclusion of evidence-was crucial to the vimdication of constitutional rights recognized to exist (though in a more limited form) before the 1960 s, convicted felons were seen as having almost no rights to protect. Courts simply regarded convicted persons as being beyond the protection or jurisdiction of the courts and would not consider issues relating to the substantive treatment of prisoners except occasionally at the extremes defined by cruel and unusual punishinent. ${ }^{100}$

Within the past few years there has been a dramatic reversal of this approach and hundreds of judicial decisions have curtailed correctional officials' absolute control over such inatters as reading materials, exercise of religion, visitors, hiving conditions, discipline, transfer among institutions and loss of good time. ${ }^{101}$

99. However, in states with a high degree of indeterminacy in their sentencing structure the actions and opinions of prison officials often have a decisive effect on length of incarceration. And even in jurisdictions with determinate sentences, disciplinary decisions affect good time and parole.

100. Task Force on Corrections, The President's Comm'n on LaW Enforce-

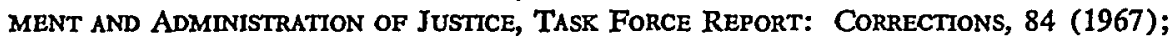
S. KRANZ, THE LAW OF Corrections and PrIsoner's Rights 325 (1973); Note, Beyond the Ken of the Courts: A Critique of Judicial Refusal to Review the Complaints of Convicts, 72 YALE L.J. 506 (1963).

101. See Turner, Establishing the Rule of Law in Prisons: A Manual for Prisoners' Rights Litigation, 23 StaN. L. REv. 473 (1971); Kimball \& Newman, Judicial Interven- 
While the judicial entry into this area has sharply curbed the unrestricted power officials exercised over their wards, it has also underlined the inadequacies of case-by-case adjudication to control a counplex area of public administration. Courts have used injunctive relief to reach the particular abuse of discretion at which they were aining, but they have found it difficult to determine whether there has been comphance with an order that a certain practice be stopped or a privilege granted. And even when there has been compliance, charges of other alleged abuses may proinptly replace any that are disposed of. In some cases courts have been drawn deeply into the administration of prisons and have faced problems similar to those of courts that have supervised school integration. ${ }^{102}$ As in the school desegregation cases, nany issues involving correctional treatment turn on the availability of resources, and this has led to confrontations between courts and legislative bodies over orders to close a jail or prison unless certain changes are made. ${ }^{103}$

In this area, as with police discretion, there are important advantages to the legislature's taking the responsibility for the content of correctional treatment rather than leaving it to judges to intervene. The most important of these advantages is that legislatures have responsibility for allocating funds and for the content of the penal code, a principal factor controlling the resources needed for corrections. Particularly in view of the mounting evidence that correctional officials do not have special knowledge about how to rehabihtate, it seems appropriate that legislatures enact a code that will deal at least in general terms with the kinds of issues that have been involved in recent judicial decisions. ${ }^{104}$

Furthermore, legislators should require correctional administrators to engage in rulemaking procedures with respect to such issues as access by visitors, use of reading materials and procedures for disciplinary hearings. These are inatters for which there already are clear practices and policies in existence and it is better to have disputes tested in the context of rulemaking procedures than in litigation of particular claims for relief. Partly as a result of the general pressure from the courts, and sometimes as a result of a specific court order to do so, some correction-

tion in Correctional Decisions: Threat and Response, 14 Crime \& Delinguency 1 (1968).

102. For a case study of the results of a federal court's efforts to overhaul the disciplinary and classification systems in a state prison, see Harvard Center for Criminal Justice, Judicial Intervention in Prison Discipline, 63 J. CRIM. L.C.\&P.S. 200 (1972).

103. See, e.g., James v. Wallace, 406 F. Supp. 318 (M.D. Ala. 1976).

104. See, e.g., CAL. PENAL CODE $§ 2600$ (West Supp. 1975); ILL. REv. STAT. ch. 38, § 1003-7-2 (1973). 
al agencies have promulgated their own rules governing such matters. ${ }^{105}$ Courts should take such rules into account in considering petitions for rehef from alleged abuses. Undoubtedly there are some issues that are less well defimed, such as access to certain programs in which there are limited places or grant of furlough privileges. As to these it would be consistent with the general approach suggested to start with more informal guidelines or after-the-fact reports.

\section{Conclusion}

The heavy rehance on discretion in criminal justice is in part a carryover from times when there was a greater sense of shared values about crime and criminal administration. People concerued about crime and those inost likely to be affected by the enforcement of criminal laws were more inclined to trust or to accept passively decisions of public officials. The erosion of this trust or acquiescence in criminal justice, as in other areas in recent times, has combined with greater worry about crime and somewhat greater awareness of the consequences of broad discretionary power to create conditions where changes seein possible.

The present doubts about discretion provide an opportunity to move toward a system of criminal administration in which the power exercised by officials is based on rational purposes and not on myth and inertia. Legislatures should take responsibility for major issues of policy and should act on those more detailed issues which they beheve are ripe for the relatively long-terin resolution involved in legislation. But it would be a mistake to seek a general legislative codification of criminal justice issues. Too much is unknown, uncertain or in flux. Some room must be allowed for the play of human mitiative if promising ideas are to be tried out in practice and new knowledge applied. When the legislature deterinimes as to specific poimts in the system that the complexity and variety of factual situations, the knowledge and skill of officials, or the need to permit modulation of the harshness of sanctions requires that there be some leeway for judgment, a grant of discretionary power may be justified. But the exercise of that power should not take the form of Delphic pronouncements by officials. They should issue exphicit statements of policy, ranging from formal rules to informal and preliminary guidelines. And with practically no exceptions, all significant decisions of officials should be announced and explained.

105. See, e.g., Lesnick, Grievance Procedures in Federal Prisons: Practices and Proposals, 123 U. PA. L. REv. 1 (1974). 
Finally, it is worth noting that the process of change froin the present heavy reliance on discretion should not be so abrupt that the effort to articulate standards and procedures results in harsh, anoinalous or foolish pronouncements or dispositions.

It is easier to make the case that the process of evolution toward greater certainty and visibility will make criminal administration fairer than that it will help reduce crime. There is ample evidence that officials often tend to use discretion to favor the powerful over the weak, although this is certainly not universally true. Greater certainty of outcome when much is at stake is a further measure of fairness. These considerations alone would justify much that is proposed here in view of the limited rational bases for inost exercises of discretion.

The argument that narrowing discretion will reduce crime is nore tenuous and must proceed on a number of levels. First, it should be noted that broad discretion does not seem to have been helpful in reducing crime. Second, there is enough common sense basis for the view that greater certainty and promptness of punishment will discourage many potential offenders to justify a major attempt to produce these conditions even if it is seen as an experiment. And, third, the greater clarity with which criminal administration can be seen and understood if decisions depend less on the unstated and unguided judgment of individuals will help achieve intended results. Thus, if it is determined that prior offenders or those who commit serious violent crimes should be taken out of circulation for a substantial period, narrowing discretion makes it more likely that such a decision will be carried out. And without such clarity the impact of experiments and innovations may be difficult to measure and the important and difficult judgments on which decisions to change are made may not be clearly perceived.

Although the past few years have been a period when inany forecasts about criminal justice have been wrong, it is still important to consider whether and how the process of narrowing official discretion is likely to proceed. Public officials, like the rest of us, are unlikely to give up power willingly or gracefully or to accept enthusiastically suggestions that the ways they are accustomed to doing things are wrong or out of date. There are some exceptions such as those judges who are so agonized about having to exercise broad discretion that they work actively to narrow it. And there are varying kinds and degrees of pressure, including public criticism, judicial intervention, and financial subventions, that may lead to greater receptivity to change. For example, the prospect of public praise or criticism, the credible threat of judicial intervention, or the promise of financial subsidies may encour- 
age officials to enunciate rules or guidelines that will govern their exercise of discretion. Thus, in seeking to predict where there may be progress in narrowing discretion it is worthwhile considering the possible sources of such pressures and, of course, the mcentives, self-confidence, and power that particular officials may have to resist them.

For some time it will probably be particularly difficult to effect major changes for the purpose of making criminal adıninistration fairer if they appear to weaken crime control. This reflects the general concern about increasing crime plus a sense, even among those who have traditionally thought of themselves as liberals on criminal justice issues, that the system has in ways that seem bizarre and unjust lost its effectiveness to deal with those who commit serious crimes. A corollary is that changes in the direction of fairness and coinpassion are most likely to be adopted if they are part of a package that is seen as including crime-reducing components. In the 1960 s community treatment won broad acceptance on this basis. Narrowed sentencing discretion and the abohition of parole may be this decade's candidates.

Changes that call for great increases in resources are likely to be particularly difficult during a period when government at all levels is being pressed to spend less. There are, however, a number of factors that may limit the effects of economic stringency on changes in criminal administration. The federal Law Enforcement Assistance program which at its height provided almost one billion federal dollars a year to state and local agencies is widely regarded as having been administered so politically and incompetently that it is possible that less money better spent may accomplish more. Further, while it would be expensive to make some of the changes that are incident to narrowing discretion, such as eliminating the use of plea bargaining to reduce caseloads, others such as narrowing sentencing discretion or bringing the detective function into the daylight might save money. And even costs that appear high may be offset by dealing with waste and inefficiency such as characterize the processing of crimmal cases in most courts. Finally, concern about crime is so great and is felt so personally that even at a time when there is little imclination to spend to help the poor, protect the environment, or improve the quality of education, there may be support for programs that seen to have something to do with safety.

A critical factor in the evolving role of official discretion will be the relationship of judicial review and oversight to other forms of guidance and control of discretion. In some areas of criminal adininistration, particularly police use of interrogation, search and seizure and identification procedures, and correctional officials' treatment of prisoners, 
courts have led the way im seeking remedies for abuses and in creating awareness of the excesses of power by those who have arrested or convicted persons in their custody. But courts are limited to cases that are brought to thein. They lack the staff and other facilities to provide continuing supervision and, most important, they do not control the resources and the general legislative power needed to make broad changes in criminal administration. The process of narrowing discretion will be promoted if courts, in protecting individuals against abuse, find ways to encourage rather than preempt the assumption of responsibility by legislatures and criminal justice officials. 
